\title{
NEO PERSONALITY INVENTORY - 3 Recenze metody
}

\author{
AUTOŘI RECENZE: DOMINIK KOVÁŘ ${ }^{1}$, BARBORA BŘEŽNÁ ${ }^{1}$
}

\begin{tabular}{|l|l|}
\hline \multicolumn{1}{|c|}{ datum vzniku recenze: } & 28.11. 2019 \\
\hline 1.1 název nástroje: & NEO osobnostní inventář - 3 \\
\hline \multicolumn{1}{|c|}{ zkrácený název: } & NEO-PI-3 \\
\hline 1.2 původní název: & NEO Personality Inventory - 3 \\
\hline 1.4 autoři původního testu: & Paul T. Costa, Robert R. McCrae \\
\hline 1.3 autoři lokální adaptace: & Martina Hřebíčková, Martin Jelínek \\
\hline 1.7 lokální distributor: & Hogrefe-Testcentrum \\
\hline $1.9 .1 / 1.9 .2$ datum vydání: & 2010 (USA) / 2016 (ČR) \\
\hline
\end{tabular}

\section{Obecné informace o metodě}

NEO-PI-3 představuje osobnostní inventář, jehož účelem je poskytnout kvantitativní popis osobnostních charakteristik jedince. Metoda předpokládá, že rysy osobnosti lze v zásadě shrnout do 5 širších dimenzí (viz dále). Nástroj je široce využíván v mnoha psychologických disciplínách, například v poradenské a klinické psychologii, pracovní psychologii a psychologii organizace práce, v pedagogické praxi a hojně je také užíván v psychologických výzkumech. Například $\mathrm{v}$ poradenské psychologii může metoda poskytnout první informace o osobnostních charakteristikách, které mohou být nápomocné pro lepší porozumění klientovi. Tento náhled může být dále také užitečný ve stanovování terapeutického postupu. Např. Shea (cit. podle manuálu, 2016) uvádí, že pro extravertní osoby trpící depresí je účinnější interpersonální terapie, zatímco pro introvertní osoby je účinnější užívání antidepresiv. Další příklad využití může být při výběru profese - profil osobnosti může napovědět, který profesní směr se zdá být vhodnější, popř. doplnit informace $\mathrm{z}$ metod diagnostikujících zájem o povolání. Kupříkladu vysoký skór v př́ípadě zájmu o podnikání může být chápán odlišně, pokud jedinec skóruje současně nízko na škále extraverze u NEO-PI-3.

\footnotetext{
${ }^{1}$ Katedra psychologie, Fakulta sociálních studií MU, Joštova 10, 60200 Brno
} 
Pro lepší porozumění metodě, níže předkládáme informace k historii vzniku metody a jejím teoretickým východiskům.

Vznik NEO vychází z původně dvou nezávislých výzkumných proudů, které se vyznačovaly odlišnými metodologickými základy. Na počátku 80. let Lewis Goldberg na základě tzv. lexikální hypotézy předpokládal, že individuální rysy osobnosti lze zachytit v analýze každodenního jazyka. V průběhu mezikulturního vývoje lidského jazyka se přirozeně objevila adjektiva, které jsou v běžném jazyce používána pro zachycení individuálních rozdílů mezi jedinci. Na základě této hypotézy předložil Goldberg v sérii studií sadu adjektiv, na které měli participanti zaznamenat, do jaké míry je daná adjektiva vystihují. Goldberg na základě výsledků faktorové analýzy popsal 5 základních dimenzí, které pojmenoval následovně: extraverze, přívětivost, svědomitost, emoční stabilita a intelekt (Block, 2010). Costa a McCrae (cit. podle Block, 2010) v roce 1980 přišli s ambicí konceptualizovat osobnost na základě 3 základních dimenzí, které měly podle nich zásadní význam pro popis osobnosti: extraverze a neuroticismus byly již v té době poměrně prozkoumané konstrukty, nezvyklé bylo zařazení Otevřenosti ke zkušenostem, což byl v té době poměrně neznámý osobnostní konstrukt. Na základě dostupných, již zavedených psychologických konstruktů rozčlenili tyto tři dimenze do 6 subškál (viz dále). Následně se inspirovali Goldbergovými výzkumy a interpretovali své dimenze jako psychologicky ekvivalentní: emoční nestabilita byla přirovnána k neuroticismu a otevřenost ke zkušenostem $\mathrm{k}$ intelektu. $\mathrm{K}$ posledním dvěma Goldbergovým dimenzím (svědomitost a přívětivost) zkonstruovali položky a vznikl tak původní nástroj označený jako NEO-PI.

V roce 1992 byla publikována revidovaná verze NEO-PI-R, která poslední dvě zmíněné dimenze rozdělila podle původního schématu na 6 subškál a přeformulovala určité položky ve 3 zbývajících faktorech. Nejnovější verze NEO-PI-3 byla publikována v roce 2010 v USA. Hlavní úprava spočívala v reformulaci 37 položek, které se jevily problematické z hlediska porozumění a psychometrických vlastností. Česká verze byla publikována v roce 2016, na rozdíl od americké verze však nemá stanovené normy pro adolescenty (viz podkapitola Normy).

Ačkoliv jsou tyto přístupy ve výsledných faktorech podobné, mají své zásadní odlišnosti. Costa a McCrae (2008) na rozdíl od Goldberga považují osobnostní dimenze za geneticky vrozené, nezávislé na vlivech prostředí, a tudíž v zásadě stabilní napříc lidským životem. Faktory osobnosti pojali hierarchicky a každou dimenzi dál dělí na 6 subškál, které by měly dimenzi popisovat.

\section{Popis škál}

Inventář se skládá celkově z 5 hlavních, teoreticky ortogonálních dimenzí, přičemž se každá dále dělí do 6 subškál. Každá subškála je reprezentována 8 položkami. Skór reprezentující jednu z hlavních dimenzí je vytvořen na základě 48 položek. Metoda tedy celkově čítá 240 položek, na které participant odpovídá na pětibodové Likertově škále 
(vůbec nevystihuje - úplně vystihuje). Dále uvádíme bližší představení jednotlivých dimenzí.

Neuroticismus vyjadřuje individuální rozdíly $\mathrm{v}$ emoční nestabilitě, tendenci zažívat negativní afektivní stavy, např. strach, úzkost, deprese atd. Dimenze má blízko k Eysenckovu pojetí emoční nestability. Dimenze je tvořena následujícími subškálami: úzkostnost, hněvivost (hostilita), depresivnost, rozpačitost, impulzivnost, zranitelnost. Extraverze se $\mathrm{v}$ pojetí autorů metody vztahuje $\mathrm{k}$ tendenci aktivně se zapojovat do společenských interakcí. Lidé s vysokou extraverzí jsou tedy přátelští, hovorní, ale také veselí, optimističtí a energičtí. Dimenze je tvořena následujícími subškálami: vřelost, družnost, asertivita, aktivnost, vyhledávání vzrušení, pozitivní emoce. Otevřenost ke zkušenostem postihuje jedincovo zaujetí pro nové zkušenosti, podněty a dojmy. Člověk s vysokým skórem na této škále má bohatou představivost, je vnímavý ke svým emocím, vyhledává rozmanitost a snaží se o nezávislý úsudek. Dimenze je tvořena následujícími subškálami: fantazie, estetické prožívání, prožívání, novátorské činnosti, ideje, hodnoty. Přívětivost popisuje individuální rozdíly v prosociálním chování a v důvěře druhým lidem. Lidé s vysokým skórem přistupují k druhým s důvěrou a chovají se k nim laskavě, vlídně a nesobecky. Dimenzi tvoří následující subškály: důvěra, upřímnost, altruismus, poddajnost, skromnost, jemnocit. Svědomitost popisuje schopnost organizovat a realizovat vytyčené úkoly. Jedinci s vysokým skórem jsou vytrvalí, spolehliví, systematičtí a ctižádostiví. Dimenzi tvoří následující subškály: způsobilost, pořádkumilovnost, zodpovědnost, cílevědomost, disciplinovanost.

\section{Administrace a skórování}

Administrace může probíhat jak individuálně, tak skupinově. Při skupinové administraci je vhodné vymezit přiměřený počet respondentů a zajistit pozitivní atmosféru, která bude participanty dostatečně motivovat. Toho je možné dosáhnout mimo jiné prŕslibem a dodáním výsledků metody formou tzv. NEO souhrnu, což je arch obsahující předpřipravené interpretace hlavních škál pro 3 úrovně rysu (nízkou, střední a vysokou), který je součástí metody. Pokud je metoda administrována za účelem výzkumu, motivaci může zvýšit také stručné vysvětlení cílů výzkumu. Cílem je předejít ledabylému způsobu odpovídání a také např. zkreslení vlivem sociální žádoucnosti. Rovněž se doporučuje přečíst instrukce před celou skupinou, uvedené na přední straně seznamu položek, a zdůraznit, že se nejedná o test schopností a neexistuje zde špatná a dobrá odpověd'.

Co se pokynů k administraci týče, manuál v této oblasti poskytuje vyčerpávající množství informací, je dostatečně detailní a výstižný.

V př́ípadě administrace tužka - papír jsou odpovědi zaznamenávány do připraveného záznamového archu. Zanesené odpovědi jsou propisovány na druhou část záznamového listu obsahující klíč k vyhodnocení. Postup vyhodnocení není obtížný: spočívá ve výpočtu hrubých skórů pro jednotlivé škály a subškály a následném převodu na standardizované skóry (T-skóry či percentily) podle př́íslušné věkové skupiny. Cut-skóry pro jednotlivé 
úrovně rysu byly určeny na základě směrodatné odchylky následovně: za střední úroveň rysu se považuje oblast +/- 0,5 SD od průměru. Odchylky 0,5 až 1,5 SD představují vysokou, resp. nízkou úroveň. Výsledky vyšší než 1,5 SD jsou považovány za velmi vysokou, resp. velmi nízkou úroveň rysu. Výstupem je grafický profil osobnosti, který na základě T-skóru odkazuje na předpokládanou úroveň osobnostního rysu, tj. specifikuje nejen úroveň hlavních rysů, ale také jednotlivých subškál. Konkrétně je tedy výsledná interpretace založena na úrovni hlavních rysů a také na 30 subškálách tvořících tyto rysy. Př́padné diverzitě úrovně subškál $v$ rámci rysu je při interpretaci věnována zvýšená pozornost.

Metoda NEO-PI-3 nabízí rovněž počítačovou verzi, která je k dispozici prostřednictvím Hogrefe testsystému verze 5 (HTS 5). Tuto verzi je třeba zvlášt' zakoupit (podrobnosti jsou uvedeny na webových stránkách www.hogrefe.cz). Počítačová verze může plně nahradit administraci tužka - papír, umožňuje jak administraci, tak vyhodnocení a interpretaci. $\mathrm{V}$ tomto př́padě software poskytne výsledné hrubé skóry a T-skóry a vygeneruje také závěrečnou zprávu ve formě NEO souhrn. Možností je také přepsat výsledky z verze tužka - papír do elektronické verze.

\section{Praktické informace a předpoklady}

Doba administrace se pohybuje okolo 45 minut. Metodu lze zakoupit na stránce Hogrefe - Testcentrum. Cena úplného testového souboru činí 3500 Kč. Výhodou elektronické verze je snadnější a rychlejší vyhodnocení hrubých a standardizovaných skórů. Hogrefe Testcentrum zařazuje tuto metodu do kategorie B, tzn., že metoda je určena absolventům bakalářského a magisterského stupně akreditovaného studijního oboru psychologie.

Výhodou této metody je poměrně snadný způsob vyhodnocení a srozumitelná klasifikace osobnosti. Profil osobnosti vyjádřený v pěti základních dimenzí může poskytnout užitečné informace pro další práci s klienty, např. při výběru profese, v pedagogické praxi či v poradenské psychologii. Tato klasifikace osobnosti podle nás navíc umožňuje získat informace, které by nám v osobním kontaktu s klientem mohly uniknout, či pokud bychom rádi přesněji zjistili míru daného rysu. Síla metody tkví také ve stanovování interpersonálních stylů. Ty lze určit na základě kombinací jednotlivých rysů a následně využít interpretaci doporučovanou manuálem. Tyto interpersonální styly následně umožňují daleko hlubší možnost interpretace. Nabízejí nám celistvější pohled na osobnost, než kdybychom chápali rysy odděleně, bez vzájemné interakce.

Základní předpoklad na straně respondentů je bezproblémové porozumění otázkám a věk odpovídající dostupným normám, tj. 20 - 76 let (viz podkapitola Normy). Předpokladem použití na straně administrátora je důkladné seznámení se s manuálem, obzvláště s částí upřesňující správnou interpretaci jednotlivých škál. Zde je manuál poměrně vyčerpávající, kromě popisu škál uvádí také tři kazuistiky, které jsou pro pochopení užitečné a usnadňují porozumění interpretaci. Míra popisu je na adekvátní úrovni, uživatel si díky uvedeným informacím vytvoří dostatečný přehled o jednotlivých škálách. 
Ačkoliv je popis poměrně detailní a srozumitelný, jedná se převážně o pouhou deskripci vyjádřenou v přídavných jménech, za škálami nestojí žádná teorie sloužící jako explanační rámec. Jako nevýhodu vidíme nevyužívání chyby měření a intervalů spolehlivosti při výsledné interpretaci. Ačkoliv si je může uživatel sám spočítat, domníváme se, že by manuál měl uživatele explicitně vybízet.

\section{Lži škály}

Inventář neobsahuje žádné „validizační“ či „lži“ škály. Na závěr vyplnění jsou položeny pouze 3 jednoduché položky. A) „Snažil jsem se odpovídat upřímně“. Na tuhle položku odpovídají participanti na pětibodové škále (vůbec nevystihuje - úplně vystihuje). V př́padě, že participant odpoví „spíše nevystihuje“ nebo „úplně nevystihuje“, odpovědi se zpravidla nevyhodnocují. Můžeme se však ptát po užitečnosti takové položky, navíc s přihlédnutím ke zjištěním Costy a McCrae (1992a, cit. podle manuálu, 2016), kteří uvádějí, že 99 \% respondentů odpoví na tuto položky „spíše vystihuje“ nebo „úplně vystihuje“. Poslední dvě položky B) „Odpověděl(a) jste na všechny výroky?“ a C) „Zaznamenal(a) jste své odpovědi na správné místo?“ by měly vést participanta k překontrolování svých odpovědí a k př́ípadnému doplnění chybějících odpovědí.

V metodě není záměrně zahrnuta škála sloužící k měření sociální žádoucnosti. Costa a McCrae (cit. podle manuálu, 2016) argumentují: výzkumy ukazují, že v mnoha případech sociálně žádoucí odpovědi neohrožují validitu škál NEO inventářů. Autoři se dále domnívají, že škály na měření sociální žádoucnosti nefungují a někdy jsou dokonce kontraproduktivní (Borkenau \& Ostendorf; Piedmont et al., oboje cit. podle manuálu, 2016). Dále předpokládají, že respondenti nezkreslují odpovědi, pokud provádějí sebeposouzení na základě vlastního zájmu. Jak ukazují experimentální výzkumy (Paulhaus, Bruce \& Trapnell, 1995), dopad sociální žádoucnosti na zkreslení výsledků se různí na základě testové situace, např. vyšší sociální žádoucnost při přijímacím řízení. Proto je zásadní vzít do úvahy kontext, v němž budou výsledky využity, abychom minimalizovali dopad sociální žádoucnosti. Použití v kontextu personalistiky může být problematické obzvláště v případě, kdy respondenti vědí, že se na základě nich budou činit nějaké důležité závěry. Např. předpokládat, že jsou výsledky svědomitosti validním ukazatelem reálné svědomitosti uchazečů o povolání, je více než diskutabilní. Výzkumy (Bäckström, 2007; Musek, 2007) dále ukazují, že sociální žádoucnost hraje roli i v neutrálním kontextu, kdy jsou výsledky anonymní a slouží pro účely výzkumu. Jak ukazuje Bäckström, Björklund a Larsson (2009), korelace mezi faktory může být vysvětlena hlavním faktorem, který se vztahuje k sociální žádoucnosti. Ve svém výzkumu porovnávali originální položky s nově formulovanými položkami mající neutrálnější valenci (např. „O druhé se př́liš nestarám“ vs. „Věřím, že je lepší, když se každý stará sám o sebe"). Výsledný rozdíl ve skórech mezi originálními a neutrálními položkami byl střední velikosti účinku. Velikost rozdílu byla také moderována skórem na škále měřící sociální žádoucnost: vysoké skóre sociální žádoucnosti souviselo s podstatnějším 
rozdílem mezi položkami než nízké skóre na této škále. Tato reformulace položek navíc vedla k podstatnému snížení společného rozptylu mezi faktory.

Z těchto informací vyplývají dva základní poznatky. Zaprvé, kontext, ve kterém administrace probíhá, má na sociální žádoucnost zásadní vliv a je třeba ho vzít do úvahy při plánovaném vyšetření. Zadruhé, sociální žádoucnost pravděpodobně hraje určitou roli i v neutrálním prostředí, korelace mezi faktory je do jisté míry způsobena právě společnou sociální žádoucností. Nezdá se však, že by tohle zkreslení nějakým zásadním způsobem ohrožovalo kriteriální validitu metody. Měření by však bylo přesnější v případě neutrální formulace položek a domníváme se, že by se o tento předpoklad mělo usilovat.

\section{Psychometrické vlastnosti metody Reliabilita}

Reliabilita české verze metody byla ověřována pouze na základě Cronbachova koeficientu alfa měřící vnitřní konzistenci položek. Ta se pohybuje v rozmezí hodnot od 0,9 po 0,94 pro hlavní škály. Vnitřní konzistence subškál se pohybuje od 0,43 pro subškálu hodnoty po 0,85 pro subškálu depresivnost. Většina subškál má uspokojivou reliabilitu (tj. nad 0,70), problematické jsou 4 subškály mající reliabilitu pod 0,69. Jedná se o subškály poddajnost, hodnoty, aktivnost a impulzivnost. Všechny tyto subškály s výjimkou impulzivnosti jsou problematické napříč různými národnostními verzemi. Costa a McCrae (cit. podle manuálu, 2016) argumentují, že tyto škály vykazují retestovou stabilitu a mají vysokou korelaci s kritériem. Zmiňují klasickou úvahu, že vysoká vnitřní konzistence může souviset jen s využitím obsahově shodných položek. Nízká vnitřní konzistence problematických subškál je způsobena obsahově odlišnými položkami, které však podle autorů přesto měří stejný rys. Medián Cronbachovy $\alpha$ je 0,91 pro hlavní škály a 0,79 pro subškály. Test-retest reliabilita není pro českou verzi metody určena. Americká studie (Costa, Herbst, McCrae, \& Siegler, 2000) poskytuje poměrně vysokou test-retest reliabilitu na vzorku 2274 participantů měřenou pomocí Pearsonovy korelace po 9 letech. Korelace se pohybuje v rozmezí od 0,76 do 0,84 pro hlavní škály a od 0,64 do 0,80 pro subškály. Medián těchto hodnot je 0,72 . Jelikož i jiné zahraniční studie poskytují obdobné hodnoty (McCrae, Yik, Trapnell, Bond, \& Paulhus, 1998; Rantanen, Metsäpelto, Feldt, Pulkkinen, \& Kokko, 2007), můžeme předpokládat, že se dají výsledky do jisté míry generalizovat i na české prostředí. Validizační studie, která by určila test-retest reliabilitu pro českou verzi, by nicméně nepochybně byla užitečná.

Ve shrnutí můžeme říci, že vnitřní konzistence jednotlivých škál je na adekvátní, až dobré úrovni, pouze 4 škály ji mají neadekvátní. Pokud bychom vzali do úvahy také zahraniční studie, test-retest variabilita je napříč škálami dobrá až vynikající. Z toho vyplývá, že pokud generalizujeme test-retest reliabilitu na české prostředí, můžeme říci, že je metoda poměrně spolehlivá a např́íc opakovanými měřeními dosáhneme obdobných výsledků.

\section{Validita}


Validita NEO-PI-3 je v manuálu posuzovaná zejména $\mathrm{z}$ hlediska vztahů rysů v rámci příslušné teorie, tedy $\mathrm{z}$ hlediska konstruktové validity. Vzhledem $\mathrm{k}$ tomu, že ani v České republice a ani v USA nejsou k dispozici údaje o validitě NEO-PI-3 (s výjimkou studie Hřebíčkové a Jelínka z roku 2019, která zjišt'ovala faktorovou strukturu NEO-PI-3, viz podkapitola Faktorová struktura), byly pro validizaci použity údaje z validity jiných inventářů (např. NEO-PI-R, NEO-FFI). Je tedy nutné zdůraznit, že žádná z validizačních studií není provedena přímo s inventářem NEO-PI-3.

NEO-PI-R a NEO-PI-3 mají velmi podobnou strukturu, lze proto předpokládat, že i korelace $s$ jinými psychologickými nástroje by v případě NEO-PI-3 byly podobné. NEO-FFI je zkrácenou verzí NEO-PI-R, která dosahuje relativně dobré shody s NEO-PI-3 a kdy průměrná hodnota společného rozptylu napříč škálami je 83,3 \% (Hřebíčková \& Jelínek, 2019).

Posuzování validity se drží teoretického rámce, ze kterého NEO inventáře vycházejí, tj. faktorový model analýzy slov používaných v přirozeném jazyce pro popis osobnosti. Validizace byla založena na korelaci mezi sebeposouzením na škálách NEO a sebeposouzením podle adjektiv reprezentujících pětifaktorovou strukturu osobnosti v češtině. Korelace mezi škálami NEO-FFI a sebeposouzením podle adjektiv byla od $0,17 \mathrm{v}$ případě otevřenosti vůči zkušenosti, po 0,72 v případě svědomitosti. Nízká korelace v př́́padě otevřenosti vůči zkušenosti je podle autorů validizační studie důsledkem odlišného obsahu českého faktoru a faktoru v NEO inventářích.

Uspokojivější výsledky přinesla validizační studie Hřebíčkové (2011, cit. podle manuálu) o korelacích NEO-PI-R pro sebeposouzení a posouzení někým jiným s Inventářem přídavným jmen (IPJ-R), tj. se škálami adjektiv vybraných jako markery pětifaktorové struktury z lexikální analýzy. Korelace se v tomto případě pohybovala od 0,36 v prípadě přívětivosti po $0,81 \mathrm{v}$ případě svědomitosti. Celkově $\mathrm{z}$ validizačních studií vyplynulo, že nejvíce se od faktoru NEO inventářů s inventáři adjektiv (lexikálního faktoru) odlišuje otevřenost vůči zkušenosti.

Posouzení celkové validity metody je poměrně obtížné z toho důvodu, že různé subškály dosahují různě vysokých korelací. Nízké korelace dosahuje zejména metoda NEO-FFI se sebeposouzením podle adjektiv. Tuto korelaci je ale z důvodu odlišného obsahu českého faktoru a faktoru NEO možné v celkovém hodnocení validity metody pominout. Pokud tedy nebudeme brát výše zmíněnou nízkou korelaci v potaz, dosahují zbylé korelace obstojných až dobrých výsledků. Velikost těchto korelací můžeme podle našeho názoru považovat za jeden z důkazů podporující celkovou validitu metody.

Dále se posuzování validity soustředí okolo shody posuzovatelů na škále NEO-PI-R, a to jak mezi sebeposouzením a posouzením někým jiným (self-other agreement), tak i okolo míry shody při posouzení jednoho člověka dvěma jinými lidmi (other-other agreement). Tyto shody jsou pro validitu metody velmi relevantní, jelikož teorie stojící za metodou předpokládá, že základních 5 rysů osobnosti je vrozených, majících neurobiologické koreláty (Costa \& McCrae, 2008). Pokud metoda skutečně popisuje rysy osobnosti, které 
se objektivně projevují a jsou poměrně nezávislé na situačním kontextu, měly by vykazovat poměrně vysokou míru shody mezi sebeposouzením a posouzením osobou, která je cílené osobě blízká. Průměrná míra shody mezi posuzovateli byla $\mathrm{r}=0,56 \mathrm{u}$ hlavních škál, vyšší než v případě ruské či americké verze. Na úrovni jednotlivých subškál dosahovala míra shody od 0,33 do 0,62 s průměrnou korelací 0,48. Medián korelace mezi sebeposouzením a posouzením partnerem dosahoval napříč kulturami hodnot od 0,42 pro svědomitost do 0,57 pro extraverzi. Celkově se medián míry shody pro sebeposouzení a posouzení jiným (partnerem, známým, rodinným příslušníkem) a posouzení dvěma třetími osobami pohyboval od 0,40 pro př́větivost po 0,45 pro extraverzi (McCrae a kol., 2004). Obecně nejvyšších hodnot dosahovala extraverze, ve výjimečných případech až korelace okolo 0,70 (sebeposouzení a posouzení jiným), nejnižších zase přívětivost a otevřenost ke zkušenostem, někdy až 0,27 .

Tvrzení, že shoda mezi posuzovateli představuje důkaz o určité objektivitě rysů osobnosti, platí pouze za předpokladu, že jsou lidé opravdu schopni tyto projevy rysů v chování druhých rozpoznat. John a Robins (cit. podle Szarota, Zawadzki, \& Strelau, 2002) uvedli seznam podmínek na kterých závisí míra shody: 1) posuzovaný rys osobnosti (obecně se ukazuje, že rysy, které většina autorů považuje za temperamentové (tj. extraverze a neuroticismus), dosahují větší míry shody), 2) pozorovatelnost daného rysu, 3) sociální žádoucnost daného rysu, 4) míra blízkosti mezi osobami, 5) schopnost posouzení dané osoby (např. ženy dosahují vyšší shody). Rovněž Funder a Dobroth (1987) zjistili, že projevy spojené s extraverzí jsou obvykle ostatními lidmi snadno identifikovány a ti tak tedy při jejich hodnocení u jiných dosahují větší míry shody. Odlišné závěry však přinášejí ohledně neuroticismu: projevy spojené s neuroticismem jsou podle nich méně viditelné a hůře identifikovatelné, shoda je tedy nižší.

Míra shody však ještě nemusí znamenat objektivitu, jelikož sebeposouzení nemusí být spolehlivým zdrojem informací. Mezi základní zkreslení patří sebeprezentace, sebeklamání (self-deception), sociální žádoucnost. Některé položky mohou být obtížné na posouzení (např. nevytahuji se) nebo mohou být hodnoceny správně pouze ostatními, napřr. v př́padě, kdy člověk naprosto souhlasí s tím, že je skromná osoba, vypovídá to spíše o jeho neskromnosti. Druhou možností je popřít daný rys, což by v tomto př́padě o skromnosti vypovídalo více (Hofstee, cit. podle Szarota, Zawadzki \& Strelau, 2002). Z toho vyplývá, že jako důkaz o objektivitě rysů považujeme korelaci dvou zdrojů, které podléhají určitým zkreslením. Korelace mezi těmito zdroji se neukazuje jako extrémně nízká, ani extrémně vysoká. Na druhou stranu se př́liš vysoká korelace ani nedá očekávat, jelikož obě posouzení vycházejí z odlišných pozic a podléhají odlišným zkreslením. Podle nás míra shody přispívá k celkovým důkazům o validitě rysů této metody.

Konvergentní a divergentní validita byla ověřována pomocí multi-trait-multi-method (MTMM) matice, kde byla zaznamenána korelace NEO-PI-R aneverbálního obrázkového testu sloužícího ke zjištění osobnostních rysů (viz např. Hřebíčková, 2010), který by měl odpovídat vlastnostem obsaženým $\mathrm{v}$ pětifaktorovém modelu, a IPJ-R (Inventář přídavných jmen). Inventáře NEO-PI-R a IPJ-R byly použity jak pro sebeposouzení, tak pro 
posouzení někým jiným. Validita byla rovněž ověřována MTMM maticí pro inventář NEOFFI a dá se předpokládat, že tyto závěry budou pro zjištění validity rovněž směrodatné.

V MTMM byly korelační koeficienty v diagonálách vždy vyšší než korelační koeficienty mimo diagonály ( $v$ diagonálách nabývaly korelační koeficienty hodnot od 0,20 do 0,93), medián těchto hodnot je 0,47 . Nejnižší korelace 0,20 byla zjištěna $v$ případě škály svědomitost mezi NEO-FFI pro posouzení někým jiným a obrázkovým testem. Důkazy o diskriminační validitě metody přinášejí nízké korelační koeficienty (od 0,00 do 0,36), které se nacházejí mimo diagonály.

Je nutno podotknout, že výše zjištěný medián korelačních koeficientů v diagonálách MTMM matice může být nadhodnocován korelací mezi testy NEO-PI-R a NEO-FFI, které jsou si velmi podobné (viz výše). Na druhou stranu můžou jeho hodnotu naopak podhodnocovat korelace mezi škálami IPJ-R a obrázkovým testem, což pro validitu metody NEO-PI-3 není nijak relevantní.

Specificky jsme tedy dále zjišțovali medián korelací v př́́padě jednotlivých škál mezi NEOPI-R a IPJ-R, který byl $r=0,78$ pro sebeposouzení, tedy poměrně vysoký. Mezi NEO-PI-R a obrázkovým testem byl medián korelací pro jednotlivé škály $r=0,53$, rovněž pro sebeposouzení. Takováto úroveň se dá hodnotit jako adekvátní až dobrá.

Tyto informace přinášejí důkazy o konstruktové validitě metody, nebot' nejvyšší korelace v MTMM matici dosahují tytéž rysy měřené jinými metodami. Korelace mezi nimi, a tedy i důkazy o konstruktové validitě, by se daly považovat za uspokojivé.

V neposlední řadě je uvedena validizační studie z prostředí brněnských gymnázií, kde na kohortě ve věku 11-13 let bylo zjištěna korelace s Eysenckovou škálou B-J.E.P.I. zjišt'ující míru neuroticismu, extraverze a psychoticismu. Korelace se pohybuje od - 0,49 (psychoticismus - přívětivost) po 0,75 (extraverze - extraverze).

Kriteriální validita byla ověřována na základě predikce určitého kritéria. V zahraničních studiích bylo zjištěno, že prediktorem rasových a jiných předsudků je nízká míra otevřenosti vůči zkušenosti a přívětivostí (oboje $r=-0,49$ ) (Ekehammar \& Akrami, 2007), souvislost byla nalezena mezi př́větivostí a tendencí odpouštět druhým $(r=0,50)$, neuroticismus souvisí negativně s tendencí odpouštět sám sobě $(r=-0,62)$ (Ross, Kendall, Matters, Wrobel, \& Rye, 2004). Dále svědomitost negativně souvisí s absencí ve škole (reportovanou jak učitelem, tak studentem) a se studijním průměrem (GPA). Korelace v tomto případě byla $r=0,35 \mathrm{v}$ případě GPA, resp. $r=0,34 \mathrm{v}$ případě docházky (Conard, 2006; Farsides \& Woodfield, 2003). Jednotlivé škály a subškály predikují také specifické projevy chování (Paunonen \& Ashton, 2001). Např. subškály altruismus, upřímnost, jemnocit, důvěra a skromnost korelovaly společně s mírou ochoty půjčovat peníze $(\mathrm{r}=$ $0,48)$. Míra, s jakou studenti navštěvují párty, korelovala společně s hlavními škálami ( $\mathrm{r}=$ 0,43). Specifičtější způsoby chování (např. nakupování losů v loterii, pravidelné cvičení) korelují se škálami slabě $(r=0,17 ; r=0,21)$. Obecně jsou subškály přesnějšími prediktory specifického chování. Celkově hodnotíme kriteriální validitu jako uspokojivou. Z našeho 
shrnutí vyplývá, že je tato metoda schopna predikovat určité specifické projevy chování, které jsou pro obsah dané škály smysluplné (např. souvislost neuroticismu s tendencí odpouštět sám sobě).

Většina těchto údajů pochází ze zahraničních studií prováděných na NEO-PI-R. Jak píše Hřebíčková a Jelínek (2019) hlavním omezením české validizační studie je absence důkazů konvergentní a kriteriální validity. Nutná by byla administrace metod měřících obdobné teoretické konstrukty a predikce vymezených psychologických charakteristik či určitého chování, např. akademická úspěšnost, životní spokojenost.

\section{Faktorová struktura}

Pětifaktorová klasifikace osobnosti není přijímána bez výhrady. Např. Block (2010) se vymezuje a upozorňuje, že faktorovou analýzu nemůžeme ztotožňovat s realitou, poskytuje nám pouze různé variace možného výkladu reality.

Někteří autoři předpokládají hierarchickou strukturu faktorů. Např. Eysenck (1992) předkládá, že svědomitost a přívětivost jsou subfaktory psychoticismu, jiní autoři zase předpokládají, že faktory mají různou hierarchickou strukturu. Např́klad DeYoung, Peterson a Higgins (cit. podle Bäckström, Björklund, \& Larsson, 2009) dokládají, že struktura loadingů může být vysvětlena existencí dvou faktorů vyššího řádu, které nazývají plasticita a stabilita. Další navrhovaný hierarchický model je komplexně strukturovaný tak, že na vrcholu struktury je jeden jediný faktor, který se manifestuje (realizuje) skrze dva faktory nižšího řádu do pěti, šesti, či možná sedmi výsledných faktor (Ashton, Lee, \& Golderg, 2004, cit. podle Bäckström, Björklund, \& Larsson, 2009).

V českém prostředí (konkrétně na české verzi NEO inventářů) byla zkoumána faktorová struktura pomocí explorační faktorové analýzy Hřebíčkovou a Urbánkem (2001, cit. podle Hřebíčková, Jelínek, 2019), a to s různými způsoby rotace, přičemž ve faktorové struktuře nebyl rozdíl (původní Goldbergova teorie postuluje, že faktory jsou navzájem ortogonální, jiní to ale vyvracejí a požadavek na nekorelovanost považují za nerealistickou podmínku (viz Block, 2010)). Dále bylo při ověřování faktorové struktury NEO-PI-3 Hřebíčkovou a Jelínkem (2019) extrahováno pět faktorů, přičemž všechny subškály dosahují alespoň faktorového náboje 0,40 a většího na předmětném faktoru. Pouze v 5 př́padech se objevily sekundární faktorové náboje na dalších subškálách. Costa a McCrae (cit. podle Hřebíčková a Jelínek, 2019) považují sekundární faktorové náboje za přiměřené tehdy, když se dají věcně interpretovat. Např́íklad subškála vřelost (která by měla spadat pod škálu extraverze) má sekundární faktorový náboj na hlavní škále přívětivosti $(0,46)$, tuto subškálu však původně Goldberg (cit. podle Hřebíčková a Jelínek, 2019) zahrnul právě pod přívětivost. Subškála vřelost má svým obsahem blízko k oběma hlavním škálám, rozdíly jsou nepatrné. Tato faktorová struktura mimo jiné dosahovala shody mezi metodami NEO-PI-3 a NEO-PI-R a taktéž mezi českou a americkou verzí NEO-PI-3.

Konfirmační faktorová analýza provedená na českém vzorku dosahovala slabé shody modelu s daty, a to CFI = 0,611 a RMSEA $=0,121$ v prrípadě modelu s korelovanými faktory, 
CFI $=0,560$ a RMSEA $=0,127$ v případě modelu s nekorelovanými faktory. Hřebíčková a Jelínek (2019) k provedené analýze uvádějí, že zátěže jednotlivých subškál odpovídajících faktorů jsou na akceptovatelných úrovních.

Výsledky EFA naznačují, že je faktorová struktura metody na uspokojivé úrovni. Faktorové náboje jsou na př́íslušné škále vždy vyšší než 0,40 , sekundární faktorové náboje se objevily pouze v pěti př́padech. Výsledky CFA již tak uspokojivé výsledky nepřinesly. $\mathrm{V}$ tomto případě se projevuje problém ortogonality jednotlivých dimenzí osobnosti tak, jak je pětifaktorový model osobnosti postuluje. I přesto, že v konfirmační faktorové analýze byly faktory korelované, nedosahuje celkový model př́liš dobré shody s daty (ač dosahuje lepší shody než ortogonální model) a nepřináší tak dobré důkazy o validitě.

\section{Standardizace české verze}

Inventář byl do češtiny přeložen nezávisle na sobě třemi osobami - psychologem, profesionálním překladatelem a jedním z autorů příručky. Ti pak na základě vzájemné diskuse dospěli k závěrečnému znění položek. Problémy s překladem se objevily zejména v případě položek postihujících způsoby chování a životní styl obvyklý v USA a vztahující se k tamní kultuře (není již ovšem zmíněno, jak s nimi naložili). Položky pak byly profesionálním překladatelem zpět přeloženy do angličtiny a revidovány rodilým mluvčím. $\mathrm{V}$ tomto znění byly odeslány autorům metody, kteří se $\mathrm{k}$ nim vyjádřili a doporučili dílčí úpravy $\mathrm{v}$ případech, $\mathrm{v}$ nichž došlo při překladu podle jejich názoru $\mathrm{k}$ posunu významu. Na základě těchto připomínek byla provedena revize položek a byla vytvořena závěrečná verze inventáře. Inventář NEO-PI-3 obsahuje položky $v$ již revidovaném znění z roku 2014, včetně změny formulací v některých položkách.

\section{Normy}

Normy byly vytvořeny na českém vzorku čítajícím celkem 1639 respondentů ve věku od 20 do 76 let, kterým byl inventář administrován převážně v elektronické verzi, přičemž normy byly výsledně tvořeny rozdílně pro muže a pro ženy a zároveň rozdílně pro kohortu pod 30 let a od 30 let výše (důvody pro toto věkové rozdělení nejsou v manuálu obsaženy). Normy pro kohortu mladší třiceti let byly zjišt'ovány na vzorku 752 respondentů (57 \% ženy), normy pro kohortu třicet let a výše byly zjišt'ovány na vzorku 887 respondentů (51 \% žen). Těžko říci, nakolik lze informace o dosaženém vzdělání respondentů brát jako relevantní, nebot’ součet procentuálního zastoupení pro jednotlivé úrovně vzdělání uvedený v manuálu mírně přesahuje $100 \%$. V úvahu přichází pochybení autorů při zaokrouhlování. Zastoupení respondentů vyučených nebo se základním vzděláním bylo 6,25 \%, vzdělání ukončené maturitou mělo 45,70 \% a 48,09 \% respondentů uvedlo vysokoškolské vzdělání.

Sběr dat byl realizován na základě nahodilého výběru: bylo osloveno 35 studentů psychologie z Prahy, Brna a Olomouce, kteří s jeho vyplněním oslovili své příbuzné, známé a přátele. 


\section{Závěr}

Co se spolehlivosti metody týče, jednotlivé škály mají uspokojivou vnitřní konzistenci, která je pro zamýšlené účely metody použitelná. Pokud generalizujeme zjištění ze zahraničních studií, výsledky jsou stabilní jak po jednom týdnu, tak i dvou či devíti letech od posledního měření. Můžeme tedy předpokládat, že se při opakovaném měření dostaví obdobné výsledky. Co se týče validity metody, výsledky explorační faktorové analýzy jsou uspokojivé, zamýšlenou faktorovou strukturu lze nalézt např́íc kulturními kontexty. Konfirmační faktorová analýza nepřinesla př́liš dobrou shodu modelu s daty. Jednotlivé škály korelují uspokojivě se sebeposouzením podle adjektiv s výjimkou v př́padě Otevřenosti vůči zkušenostem. Tato škála se ukazuje jako problematická, s adjektivy totiž příliš nekoreluje, což může být způsobeno odlišným obsahem tohoto faktoru ve srovnání s NEO inventáři. Metoda dále dosahuje adekvátních korelací s obdobnými konstrukty (viz Eysenckova škála) a ze zahraničních studií vyplývá, že škály predikují různá kritéria poměrně obstojně. Obecné způsoby chování metoda predikuje lépe, např. otevřenost vůči zkušenosti a přívětivost je prediktorem rasových předsudků (oboje $r=-0,49$ ), než specifické způsoby chování, např. pravidelné cvičení ( $\mathrm{r}=0,21)$. Ve shrnutí můžeme říct, že je reliabilita a validita metody obstojná.

Závěrem tedy považujeme metodu NEO-PI-3 za užitečný nástroj, který nabízí určitou možnost systematického porozumění osobnosti a vymezených 5 faktorů za jeden ze způsobů, jak klasifikovat osobnostní strukturu. Zásadní je však kontext použití, detailní znalost jednotlivých subškál a realistický přístup k využití metody. Navíc formulace některých položek se zdá vybízet $\mathrm{k}$ sociální žádoucnosti (např. považuji se za dobročinného člověka) či mohou být obtížné na osobní posouzení (např. nevytahuji se).

Z těchto informací bychom rádi na závěr formulovali několik doporučení: Zaprvé, při poradenství či v rámci terapie doporučujeme využívat tuto metodu po osobním poznání klienta a za vyjasněným účelem. V tomto kontextu se podle nás otevírá riziko, že osobnostní profil vytvoří jisté prekoncepce, na jejichž základě budeme druhého člověka vnímat, tj. budou při poznání příliš vstupovat do popředí a zkreslovat další informace.

Zadruhé, metoda by měla být využita pouze $\mathrm{v}$ kontextu, který předpokládá motivaci klienta k dobrání se co nejpřesnějších výsledků. Nevhodné je tedy využití v rámci pracovního pohovoru či testování zaměstnanců, z důvodů možného zkreslení výsledků vlivem sociální žádoucnosti (Paulhaus, Bruce \& Trapnell, 1995). Vhodné využití vidíme např. v psychodiagnostické činnosti (testování za účelem identifikace silných stránek osobnosti), ve školní psychologii (identifikace problematických stránek souvisejících s obtížemi v kolektivu), v poradenské oblasti (určení interpersonálního stylu za účelem pomoci při výběru budoucího povolání) a ve výzkumné činnosti.

\section{Literatura}


Ashton, M. C., \& Lee, K. (2007). Empirical, theoretical, and practical advantages of the HEXACO model of personality structure. Personality and social psychology review, 11(2), 150-166.

Bäckström, M. (2007). Higher-order factors in a five-factor personality inventory and its relation to social desirability. European Journal of Psychological Assessment, 23(2), 6370 .

Bäckström, M., Björklund, F., \& Larsson, M. R. (2009). Five-factor inventories have a major general factor related to social desirability which can be reduced by framing items neutrally. Journal of Research in Personality, 43(3), 335-344.

Block, J. (2010). The five-factor framing of personality and beyond: Some ruminations. Psychological Inquiry, 21(1), 2-25.

Conard, M. A. (2006). Aptitude is not enough: How personality and behaviour predict academic performance. Journal of Research in Personality, 40(3), 339-346.

Costa Jr, P. T., Herbst, J. H., McCrae, R. R., \& Siegler, I. C. (2000). Personality at midlife: Stability, intrinsic maturation, and response to life events. Assessment, 7(4), 365-378.

Ekehammar, B., \& Akrami, N. (2007). Personality and prejudice: From Big Five personality factors to facets. Journal of personality, 75(5), 899-926.

Farsides, T., \& WoodWeld, R. (2003). Individual differences and undergraduate academic success: the roles of personality, intelligence, and application. Personality and Individual Differences, 34, 1225-1243.

Funder, D. C., \& Dobroth, K. M. (1987). Differences between traits: Properties associated with interjudge agreement. Journal of personality and social psychology, 52(2), 409.

Hřebíčková, M. (2010). The Five Factor Nonverbal Personality Questionnaire in the Czech Context. Sudia psychologica, 52(3), 165-177.

Hřebíčková, M., \& Jelínek, M. (2019). NEO osobnostní inventář 3: Základní psychometrické charakteristiky české verze NEO-PI-3. Československá Psychologie, 63(2), 160-176.

McCrae, R. R., Costa, P. T., Martin, T. A., Oryol, V. E., Rukavishnikov, A. A., Senin, I. G., Hřebíčková, M. \& Urbánek, T. (2004). Consensual validation of personality traits across cultures. Journal of Research in Personality, 38, 179-201.

McCrae, R. R., \& Costa Jr, P. T. (2008). The five-factor theory of personality.

McCrae, R. R., Yik, M. S., Trapnell, P. D., Bond, M. H., \& Paulhus, D. L. (1998). Interpreting personality profiles across cultures: Bilingual, acculturation, and peer rating studies of Chinese undergraduates. Journal of Personality and Social Psychology, 74(4), 1041.

Musek, J. (2007). A general factor of personality: Evidence for the big one in the five factor model. Journal of Research in Personality, 41, 1213-1233. 
Paulhus, D. L., Bruce, M. N., \& Trapnell, P. D. (1995). Effects of self-presentation strategies on personality profiles and their structure. Personality and Social Psychology Bulletin, 21(2), 100-108.

Paunonen, S. V., \& Ashton, M. C. (2001). Big five factors and facets and the prediction of behavior. Journal of personality and social psychology, 81(3), 524.

Ross, S. R., Kendall, A. C., Matters, K. G., Mark S. Rye, M. S. R., \& Wrobel, T. A. (2004). A personological examination of self-and other-forgiveness in the five factor model. Journal of Personality Assessment, 82(2), 207-214.

Rantanen, J., Metsäpelto, R. L., Feldt, T., Pulkkinen, L. E. A., \& Kokko, K. (2007). Long-term stability in the Big Five personality traits in adulthood. Scandinavian Journal of Psychology, 48(6), 511-518.

Szarota, P., Zawadzki, B., \& Strelau, J. (2002). Big five domain and gender as determinants of rater agreement: a comparison based on self-and peer-rating on the Polish Adjective List. Personality and Individual Differences, 33(8), 1265-1277. 


\author{
EFPA \\ STANDING COMMITTEE ON \\ TESTS AND TESTING (SCTT)
}

Příloha ke Zprávě předsedy, 2005

MODEL RECENZE PODLE EFPA PRO POPIS

A HODNOCENÍ PSYCHOLOGICKÝCH TESTŮ

FORMULÁŘ RECENZE TESTU A POZNÁMKY PRO RECENZENTY

Verze 3.42

Lokální úprava pro časopis Testforum

ISSN 1805-9147 


\title{
MODEL RECENZE PODLE EFPA PRO POPIS \\ A HODNOCENÍ PSYCHOLOGICKÝCH TESTŮ \\ FORMULÁŘ RECENZE TESTU A POZNÁMKY PRO \\ RECENZENTY ${ }^{1}$
}

\author{
Toto je lokální úprava dokumentu pro účely publikace v časopise Testfórum. \\ Originální český překlad je k dispozici na stránkách EFPA \\ (www.efpa.eu/download/505cd9db4144ecb16174087909c9cd6d).
}

Původní verzi sestavil a uspořádal Dave Bartram

Doplnili a revidovali Patricia Lindley, Dave Bartram a Natalie Kennedy v dubnu $2004^{2}$

Současná verze 3.42: květen 2005

Český překlad: Tomáš Urbánek

Od uživatelů tohoto dokumentu a jeho obsahu žádá EFPA, aby uznali tento zdroj prostřednictvím následujícího textu:

"Kritéria pro recenzi testu podle EFPA do značné míry vychází z formy a obsahu kritérií pro recenze testů Britské psychologické společnosti (BPS) a kritérií vytvořených Komisí pro testové záležitosti (COTAN) Holandské asociace psychologů (NIP). Dave Bartram a Patricia Lindley původně vyvinuli kritéria BPS a recenzní procedury pro UK Employment Service a později rozšírili jejich používání pro celou BPS. Arne Evers připravil k vydání nizozemský system posuzování kvality testů.

EFPA je vděčná BPS a NIP za svolení použít jejich kritéria jako základ pro vytvoření evropského modelu. EFPA je také vděčná Davu Bartramovi, Arnu Eversovi a Patricii Lindley za jejich přispění $k$ vývoji tohoto modelu. Veškerá intelektuální vlastnická práva původních kritérií podle BPS a NIP jsou nadále uznávána a náleží těmto orgánům."

\footnotetext{
1 Tento dokument byl vytvořen z několika zdrojů, včetně Hodnotícího formuláře pro recenzi testu používaného v BPS (NPAL a Řídící komise pro testové standardy při BPS - Steering Committee on Test Standards), Španělského dotazníku pro hodnocení psychometrických testů (Španělská psychologická asociace) a Systému pro posuzování kvality testu (Komise pro testování Holandské asociace psychologů). Některé části byly adaptovány se svolením z dokumentu: BPS Books Reviews of Level B Assessment Instruments for use in Occupational Assessment, Notes for Reviewers: Version 3.1. December 1998: Copyright (C) NPAL, 1989, 1993, 1998.

${ }^{2}$ Současná verze je spojením dvou oddělených dokumentů (Formuláře recenze a Poznámek pro recenzenty). Obsah byl navíc uspořádán a doplněn na základě jeho používání recenzenty online testů v BPS.
} 


\section{Část 1:}

Popis nástroje: Obecné informace a klasifikace

\section{EFPA 3.2 reference}

\begin{tabular}{|c|c|c|}
\hline & Recenzent 1: & Bc. Dominik Kovár̆ \\
\hline & Recenzent 2: & Bc. Barbora Břežná \\
\hline & Konzultující editor: & Mgr. Jaroslav Gottfried \\
\hline & Vedoucí editor: & Mgr. Hynek Cígler, Ph.D. \\
\hline & $\begin{array}{l}\text { Vedoucí editor aktualizace: } \\
\text { (pouze v př́padě aktualizací) }\end{array}$ & \\
\hline & $\begin{array}{l}\text { Editor aktualizace: } \\
\text { (pouze v př́padě aktualizací) }\end{array}$ & \\
\hline & Datum vzniku této recenze: & 28. 11.2019 \\
\hline 1.1 & Název nástroje (lokální verze): & NEO osobnostní inventář-3 \\
\hline & Zkrácená verze názvu testu: & NEO-PI-3 \\
\hline 1.2 & $\begin{array}{l}\text { Původní název testu (pokud je lokální } \\
\text { verze adaptací): }\end{array}$ & NEO Personality Inventory - 3 \\
\hline 1.4 & Autoři původního testu: & Paul. T. Costa, Robert. R. McCrae \\
\hline 1.3 & Autoři lokální adaptace: & Martina Hřebíčková, Martin Jelínek \\
\hline 1.7 & Lokální distributor/vydavatel testu: & Hogrefe-Testcentrum \\
\hline 1.8 & $\begin{array}{l}\text { Vydavatel původní verze testu (pokud je } \\
\text { jiný než současný distributor/vydavatel): }\end{array}$ & Psychological Assessment Resources, Inc. \\
\hline 1.9 .1 & Datum vydání současné revize/vydání: & 2010 \\
\hline 1.9 .2 & $\begin{array}{l}\text { Datum vydání adaptace pro lokální } \\
\text { užívání: }\end{array}$ & 2016 \\
\hline 1.9 .3 & Datum vydání původního testu: & 1985 \\
\hline
\end{tabular}




\section{Obecný popis nástroje}

NEO-PI-3 představuje osobnostní inventář, jehož účelem je poskytnou kvantitativní deskripci osobnostní struktury. Nástroj je celosvětově široce využíván v celé škále psychologických disciplín, například v poradenské a klinické psychologii, pracovní psychologii a psychologii organizace práce, v pedagogické praxi a široce je také užíván v psychologických výzkumech. Př́ikladem využití této metody v poradenské psychologii je možnost lepšího porozumění klientovi; osobnostní profil nám může podat přibližný obraz jeho osobnostní struktury. Tento náhled může být užitečný ve stanovování dalšího terapeutického postupu. Např. Shea (cit. podle manuálu, 2016) uvádí, že pro extravertní osoby trpící depresí je účinnější interpersonální terapie, zatímco pro introvertní osoby je účinnější užívání antidepresiv. Další příklad využití může být při výběru profese - profil osobnosti může napovědět, který profesní směr se zdá být vhodnější, popř. doplnit informace $\mathrm{z}$ metod diagnostikujících zájem o povolání. Kupříkladu vysoký skór v případě zájmu o podnikání může být brán s rezervou, pokud jedinec skóruje současně nízko na skále introverze u NEO-PI-3.

Využití je u české verze zacíleno na populaci od 20 do 76 let (viz podkapitola Normy níže). Americká verze nadto nabízí normy pro adolescenty od 14 do 20 let, pro tuto věkovou skupinu však nebyly v českém prostředí normy stanoveny.

Vznik NEO vychází z původně dvou nezávislých výzkumných proudů, které se vyznačovaly odlišnými metodologickými základy. Na počátku 80. let Lewis Goldberg na základě tzv. lexikální hypotézy předpokládal, že individuální rysy osobnosti lze zachytit v analýze každodenního jazyka. $V$ průběhu mezikulturního vývoje lidského jazyka se přirozeně objevila adjektiva, které jsou v běžném jazyce používána pro zachycení individuálních rozdílů mezi jedinci. Na základě této hypotézy předložil Goldberg v sérii studií sadu adjektiv, na které měli participanti zaznamenat, do jaké míry je daná adjektiva vystihují. Goldberg na základě výsledků faktorové analýzy popsal 5 základních dimenzí, které pojmenoval následovně: extraverze, přívětivost, svědomitost, emoční stabilita a intelekt (Block, 2010). Costa a McCrae (cit. podle Block, 2010) v roce 1980 přišli s ambicí konceptualizovat osobnost na základě 3 základních dimenzí, které měly podle nich zásadní význam pro popis osobnosti: extraverze a neuroticismus byly již v té době poměrně prozkoumané konstrukty, nezvyklé bylo zařazení Otevřenosti ke zkušenostem, což byl v té době poměrně neznámý osobnostní konstrukt. Na základě dostupných, již zavedených psychologických konstruktů rozčlenili tyto tři dimenze do 6 subškál (viz dále). Následně se inspirovali Goldbergovými výzkumy a interpretovali své faktory jako psychologicky ekvivalentní: emoční nestabilita byla přirovnána k neuroticismu a otevřenost ke zkušenostem $\mathrm{k}$ intelektu. $\mathrm{K}$ posledním dvěma Goldbergovým faktorům (svědomitost a přívětivost) zkonstruovali položky a vznikl tak nástroj označený jako NEO-PI. V roce 1992 byla publikována revidovaná verze NEO-PI-R, která poslední dva zmíněné faktory rozdělila podle původního schématu na 6 subškál a přeformulovala určité položky ve 3 zbývajících faktorech. Nejnovější verze NEO-PI-3 byla publikována v roce $2010 \mathrm{v}$ USA. Hlavní úprava spočívala v reformulaci 37 položek, které se jevily problematické z hlediska porozumění. Nové položky tak dosáhly lepších psychometrických vlastností a jsou vhodnější např. pro lidi s nižším vzděláním. Česká verze byla publikována v roce 2016, narozdíl od americké verze však nemá stanovené normy pro adolescenty (viz podkapitola Normy).

Ačkoliv jsou tyto přístupy ve výsledných faktorech podobné, mají své zásadní odlišnosti. Costa a McCrae (2008) na rozdíl od Goldberga považují osobnostní dimenze za geneticky vrozené, nezávislé na vlivech prostředí, a tudíž v zásadě stabilní napříč lidským životem. Faktory osobnosti pojali hierarchicky a každou dimenzi dál dělí na 6 subškál, které by měly faktor popisovat.

Inventář se skládá celkově z 5 hlavních, teoreticky ortogonálních, dimenzí, přičemž se každá dále dělí do 6 subškál. Každá subškála je reprezentována 8 položkami. Skór reprezentující 
jednu z hlavních dimenzí je vytvořen na základě 48 položek. Metoda tedy celkově čítá 240 položek, na které participant odpovídá na pětibodové Likertově škále (vůbec nevystihuje úplně vystihuje). Dále uvádíme bližší představení jednotlivých faktorů.

Neuroticismus vyjadřuje individuální rozdíly v emoční nestabilitě, tendenci zažívat negativní afektivní stavy, např. strach, úzkost, deprese atd. Dimenze má blízko k Eysenckovu pojetí emoční nestability. Faktor je tvořen následujícími fasetami: úzkostnost, hněvivost (hostilita), depresivnost, rozpačitost, impulzivnost, zranitelnost. Extraverze se v pojetí autorů metody vztahuje $\mathrm{k}$ tendenci aktivně se zapojovat do společenských interakcí. Lidé s vysokou extraverzí jsou tedy přátelští, hovorní, ale také veselí, optimističtí a energičtí. Faktor je tvořen následujícími fasetami: vřelost, družnost, asertivita, aktivnost, vyhledávání vzrušení, pozitivní emoce. Otevřenost ke zkušenostem postihuje jedincovo zaujetí pro nové zkušenosti, podněty a dojmy. Člověk s vysokým skórem na této škále má bohatou představivost, je vnímavý ke svým emocím, vyhledává rozmanitost a snaží se o nezávislý úsudek. Faktor je tvořen následujícími fasetami: fantazie, estetické prožívání, prožívání, novátorské činnosti, ideje, hodnoty. Př́větivost popisuje individuální rozdíly v prosociálním chování a v důvěře druhým lidem. Lidé s vysokým skórem přistupují k druhým s důvěrou a chovají se k nim laskavě, vlídně a nesobecky. Faktor tvoří následující subškály: důvěra, upřímnost, altruismus, poddajnost, skromnost, jemnocit. Svědomitost popisuje schopnost organizovat a realizovat vytyčené úkoly. Jedinci s vysokým skórem jsou vytrvalí, spolehliví, systematičtí a ctižádostiví. Faktor je tvořen následujícími fasetami: způsobilost, pořádkumilovnost, zodpovědnost, cílevědomost, disciplinovanost.

\section{Část 2:}

Klasifikace

\begin{tabular}{|l|l|ll|}
\hline 1.10 .1 & Obsahová doména & $\square$ Školní schopnosti \\
& $\square$ & Všeobecné schopnosti \\
& $\square$ & Verbální schopnosti \\
& $\square$ & Numerické schopnosti \\
$\square$ & Prostorové schopnosti \\
& $\square$ & Neverbální schopnosti \\
& $\square$ & Rychlost vnímání \\
& $\square$ & Pamět' \\
& $\square$ & Manuální zručnost \\
& $\square$ & Osobnost - Rys \\
& $\square$ & Osobnost - Typ \\
& $\square$ & Osobnost - Stav \\
& $\square$ & Kognitivní styly \\
& $\square$ & Motivace \\
& $\square$ & Hodnoty \\
& $\square$ & Zájmy \\
& $\square$ & Přesvědčení \\
& $\square$ & Poruchy a patologie \\
& $\square$ & Skupinové procesy \\
& $\square$ & Rodina \\
& $\square$ & Organizace, její fungování, agregovaná \\
& $\square$ měření, klima atd. \\
& $\square$ Školní nebo výchovné funkce \\
& $\square$ Jiné: \\
&
\end{tabular}




\begin{tabular}{|c|c|c|}
\hline 1.10 .2 & $\begin{array}{l}\text { Zamýšlená(é) nebo hlavní oblast(i) } \\
\text { použití. }\end{array}$ & $\begin{array}{ll} & \text { Klinická psychologie } \\
\square & \text { Neuropsychologie } \\
\square & \text { Forenzní psychologie } \\
\bigotimes & \text { Psychologie výchovy a vzdělávání } \\
\bigotimes & \text { Psychologie práce a personalistika } \\
\bigotimes & \text { Poradenství, doporučení, vedení a volba } \\
& \text { povolání } \\
\bigotimes & \text { Psychologie zdraví, životní styl a životní } \\
& \text { spokojenost } \\
\square & \text { Sporty a volný čas } \\
\square & \text { Jiné: }\end{array}$ \\
\hline 1.10 .3 & $\begin{array}{l}\text { Zamýšlený zpo̊sob použití } \\
\text { (podmínky, za jakých byl nástroj } \\
\text { standardizován a validizován) }\end{array}$ & $\begin{array}{l} \\
\text { Nesupervidovaná administrace bez } \\
\text { kontroly nad identitou respondenta a bez } \\
\text { úplné kontroly nad podmínkami } \\
\text { administrace (např. volně př́stupný test } \\
\text { na internetu, test dostupný ke koupi v } \\
\text { knihkupectví). } \\
\square \text { Kontrolovaný nesupervidovanou } \\
\text { administrcí. Kontrola nad podmínkami } \\
\text { (čas atd.) a určitá kontrola nad identitou } \\
\text { uživatele testu (např. testy } \\
\text { administrované přes internet, ale pouze } \\
\text { známým osobám - př́stup omezený } \\
\text { heslem). } \\
\text { Supervidovaná a kontrolovaná } \\
\text { administrace. Administrace testu pod } \\
\text { kontrolou kvalifikovaného } \\
\text { administrátora nebo dohlížitele. } \\
\text { Řízená administrace. Administrace testu } \\
\text { prováděná pouze přes určená testovací } \\
\text { centra (např. programy hodnocení licencí } \\
\text { a certifikace). }\end{array}$ \\
\hline $\begin{array}{l}1.10 .4 \\
\end{array}$ & $\begin{array}{l}\text { Popis populací, pro které je test } \\
\text { určen: }\end{array}$ & Dospělá populace \\
\hline
\end{tabular}




\begin{tabular}{|c|c|c|}
\hline 1.10 .5 & $\begin{array}{l}\text { Počet škál a krátký popis } \\
\text { proměnné nebo proměnných } \\
\text { měřených nástrojem }\end{array}$ & $\begin{array}{l}\text { Metoda NEO-PI-3 obsahuje celkově } 5 \text { hlavních } \\
\text { škál. Každá škála je dále členěna na } 6 \text { subškál, } \\
\text { celkově tedy metoda čítá } 5 \text { škál a } 30 \text { subškál. } \\
\text { Neuroticismus - úzkostnost, hněvivost, } \\
\text { depresivnost, rozpačitost, impulzivita, } \\
\text { zranitelnost } \\
\text { Extraverze - vřelost, družnost, asertivita, } \\
\text { aktivnost, vyhledávání vzrušení, pozitivní } \\
\text { emoce } \\
\text { Otevřenost ke zkušenostem - fantazie, } \\
\text { estetické prožívání, prožívání, novátorské } \\
\text { činnosti, ideje, hodnoty } \\
\text { Přívětivost - důvěra, upřímnost, altruismus, } \\
\text { poddajnost, skromnost, jemnocit } \\
\text { Svědomitost - způsobilost, pořádkumilnost, } \\
\text { zodpovědnost, cílevědomost, } \\
\text { disciplinovanost, rozvážnost }\end{array}$ \\
\hline 1.11 & Formát položek & $\begin{array}{ll}\square & \text { Otevřený } \\
\square & \text { Mnohonásobná volba, alternativy na } \\
& \text { stejné škále } \\
\square & \text { Bipolární adjektiva } \\
\bigotimes & \text { Likertovy ratingy (škály) } \\
\square & \text { Nucená volba, alternativy na smíšených } \\
\text { škálách (ipsativní) - vysvětlení viz } \\
\text { Poznámky } \\
\square \text { Mnohonásobná volba, alternativy na } \\
\text { smíšených škálách (ipsativní) - } \\
\text { vysvětlení viz Poznámky } \\
\square \text { Sady párů adjektiv (sémantický } \\
\text { diferenciál), smíšené škály (ipsativní) } \\
\square \text { Jiné: }\end{array}$ \\
\hline 1.12 & Počet položek testu: & 240 položek \\
\hline 1.13 & Způsob(y) administrace: & $\begin{array}{ll}\bigotimes & \text { Interaktivní individuální administrace } \\
\bigotimes & \text { Supervidovaná skupinová administrace } \\
\square & \text { Počítačová lokálně nainstalovaná } \\
\text { aplikace - pod supervizí/dohledem } \\
\square & \begin{array}{l}\text { Počítačová aplikace na webu - pod } \\
\text { supervizí/dohledem }\end{array} \\
& \text { Počítačová lokálně nainstalovaná } \\
\text { aplikace - bez supervise/testování sebe } \\
\square \\
\text { Počítačová aplikace na webu - bez } \\
\text { supervize/testování sebe } \\
\square \text { Jiné: }\end{array}$ \\
\hline
\end{tabular}




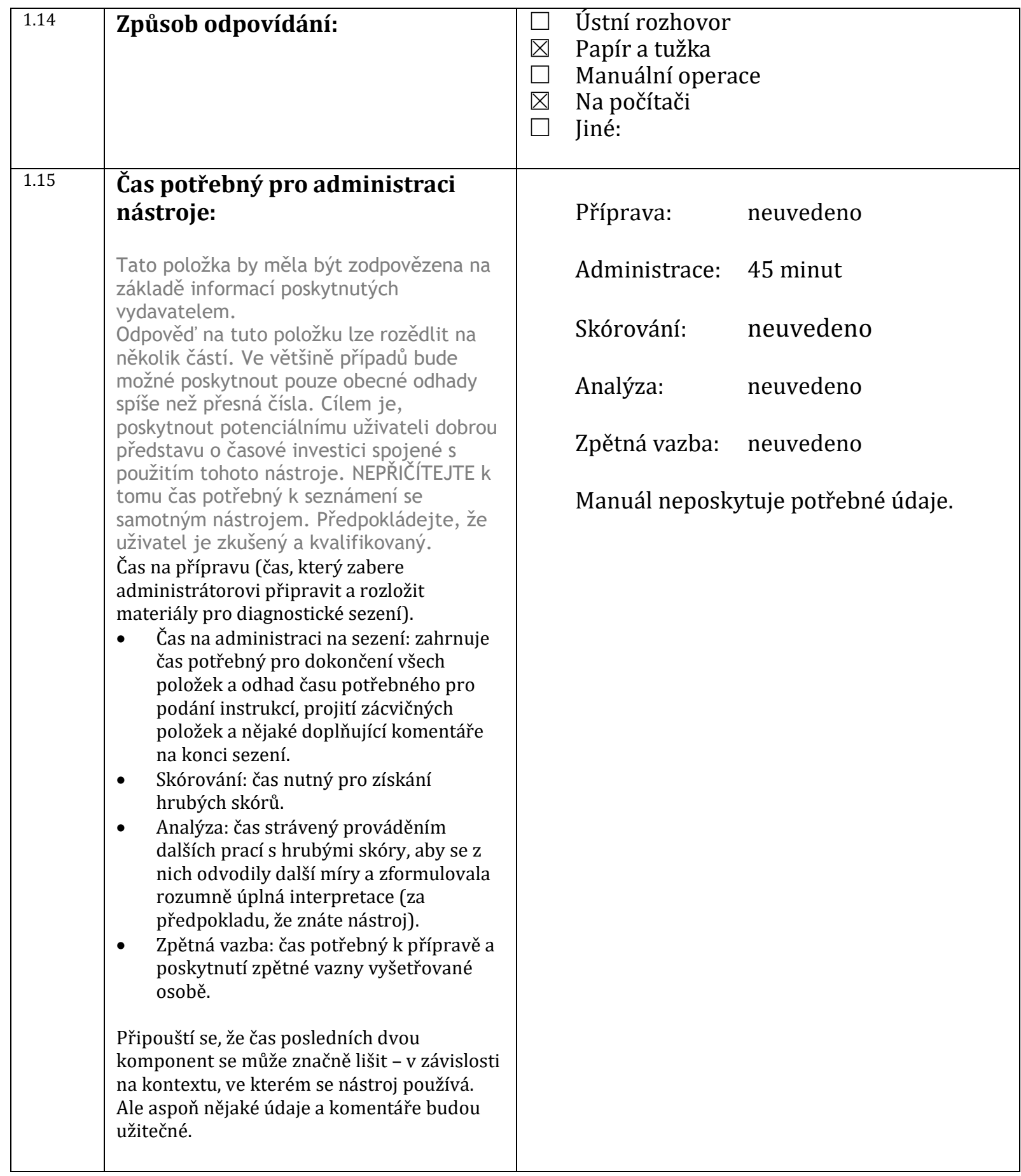




\begin{tabular}{|c|c|c|}
\hline 1.16 & $\begin{array}{l}\text { Jsou k dispozici různé formy } \\
\text { nástroje? }\end{array}$ & $\begin{array}{l}\text { Metoda NEO-PI-3 nemá } \\
\text { alternativní/ekvivalentní, ani normativní } \\
\text { formu testu. Existuje zkrácená verze této } \\
\text { metody, tzv. NEO-FFI poskytující } \\
\text { informace pouze pro } 5 \text { hlavních škál } \\
\text { měřených celkově } 60 \text { položkami. } \\
\text { Naopak metoda NEO-PI-R s podobnou } \\
\text { strukturou jako NEO-PI-3 obsahuje verzi } \\
\text { pro posouzení jiného. } \\
\text { Metoda NEO-PI-3 nabízí rovněž } \\
\text { počítačovou verzi, která je k dispozici } \\
\text { prostřednictvím Hogrefe testsystému } \\
\text { verze } 5 \text { (HTS 5). Tuto verzi je třeba zvlášt' } \\
\text { zakoupit (podrobnosti jsou uvedeny na } \\
\text { webových stránkách www.hogrefe.cz). }\end{array}$ \\
\hline
\end{tabular}

Č́ást 3:

\section{Měření a skórování}

\begin{tabular}{|l|l|ll|}
\hline 1.17 & Procedura skórování testu: & $\begin{array}{l}\text { Počítačové skórování s př́mým vstupem } \\
\text { odpovědí testovanou osobou }\end{array}$ \\
$\begin{array}{l}\text { Počítačové skórování s ručním vstupem } \\
\text { odpovědí z papírového záznamového archu }\end{array}$ \\
$\begin{array}{l}\text { Počítačové skórování odpovědí z papírového } \\
\text { záznamového archu pomocí pomocí jejich } \\
\text { načtení pomocí skeneru }\end{array}$ \\
$\begin{array}{l}\text { Jednoduchý ruční skórovací klíč - nutné } \\
\text { pouze kancelářské dovednosti }\end{array}$ \\
\end{tabular}




\begin{tabular}{|c|c|c|}
\hline 1.20 & Použité škály & 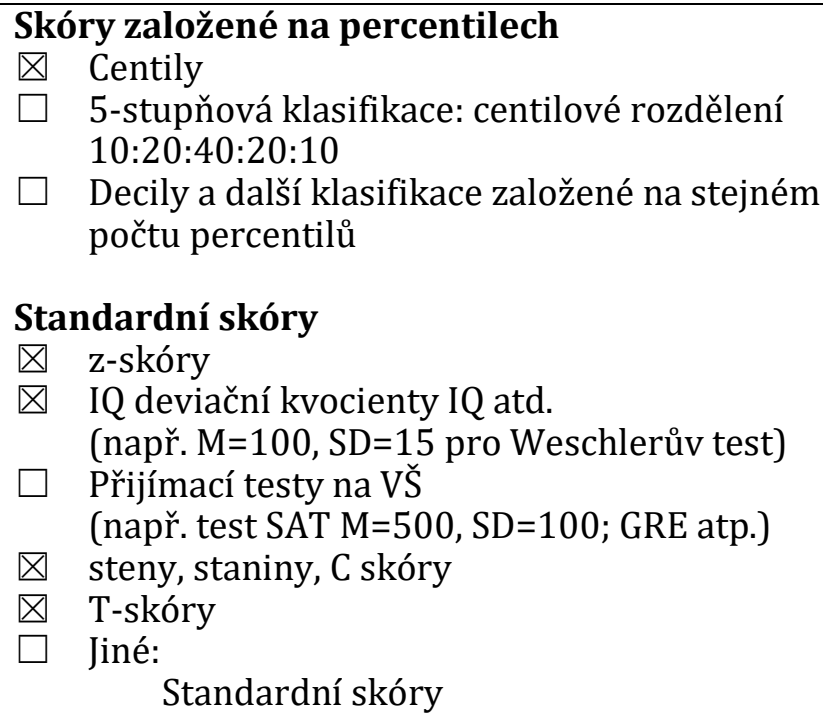 \\
\hline
\end{tabular}

\section{Č́ást 4:}

Počítačově generované zprávy

Toto je čistě popisné. Hodnocení zpráv bude součástí části recenze nazvané Hodnocení.

\begin{tabular}{|l|l|l|}
\hline 1.21 & $\begin{array}{l}\text { Jsou počítačově generované zprávy } \mathbf{k} \\
\text { dispozici s nástrojem? }\end{array}$ & $\begin{array}{l}\bigotimes \quad \text { nno } \\
\square \quad \mathrm{Ne}\end{array}$ \\
\hline
\end{tabular}

\begin{tabular}{|c|c|c|c|}
\hline 1.21 .0 & Název nebo popis zprávy: & & \\
\hline 1.21 .1 & $\begin{array}{l}\text { Média: } \\
\text { Zprávy mohou sestávat pouze z textu nebo obsahovat } \\
\text { text spolu s grafickýmin nebo tabulkovoými zobrazeními } \\
\text { skórú (naprrs. stenovými profily). Kede jsou prezentovány } \\
\text { text i data, mohou být prezentovány prostě paralelně, } \\
\text { nebo mohou být propojeny, takže vztah mezi textovými } \\
\text { výroky a skóry je explicitně vyjádřen. }\end{array}$ & & $\begin{array}{l}\text { Pouze text } \\
\text { Text a grafika bez vzájemného vztahu } \\
\text { Integrovaný text a grafika }\end{array}$ \\
\hline 1.21 .2 & 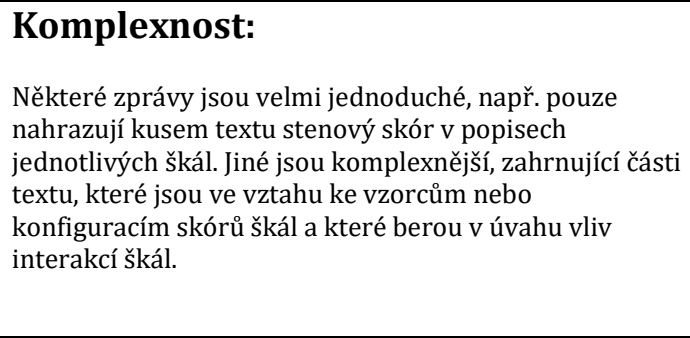 & & $\begin{array}{l}\text { Jednoduchá (Například seznam odstavců } \\
\text { podávajících popisy škál) } \\
\text { Střední (Směs jednoduchých popisů a } \\
\text { několika popisů konfigurací) } \\
\text { Komplexní (Obsahuje popisy vzorců a } \\
\text { konfigurací skórů škál a interakce škál) }\end{array}$ \\
\hline
\end{tabular}




\begin{tabular}{|c|c|c|}
\hline 1.21 .3 & $\begin{array}{l}\text { Struktura zprávy: } \\
\text { Struktura má vztah ke komplexitě. }\end{array}$ & 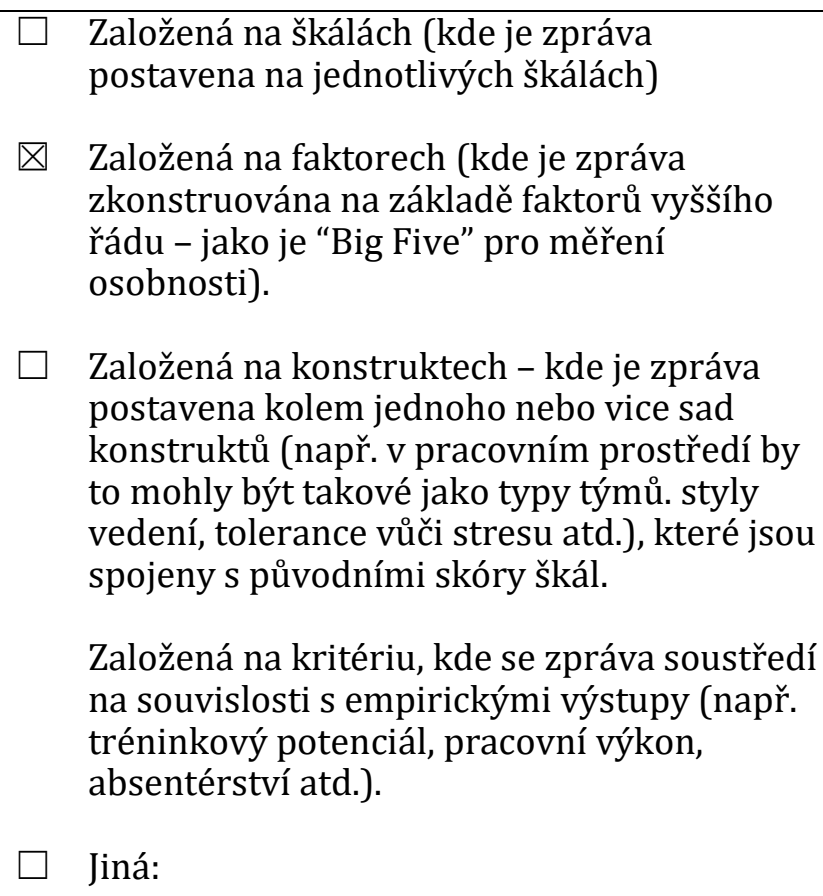 \\
\hline 1.21 .4 & $\begin{array}{l}\text { Citlivost vůči kontextu } \\
\text { Když lidé píš́ zprávy, přizpưsoboují jazyk, formu a obsah } \\
\text { zprávy osobě, která ji bude číst a berou v úvahuu ućcl } \\
\text { diagnostiky a context, ve kterém probíhá. Zpráva } \\
\text { vytvớená pro účely yýběru bude odlišná od zprávy pro } \\
\text { účely vedení nebo vývoje; zpráva pro manažera ve } \\
\text { středním věku se bude lišit od zprávy napsané pro } \\
\text { mladou osobu začínajícís tréninkovým schématem atd. }\end{array}$ & $\begin{array}{l}\otimes \quad \text { Jedna verze pro všechny kontexty } \\
\square \quad \text { Předdefinované verze pro různé kontexty } \\
\square \quad \text { Uživatelem definovatelné kontexty } \\
\text { a editovatelné zprávy }\end{array}$ \\
\hline 1.21 .5 & 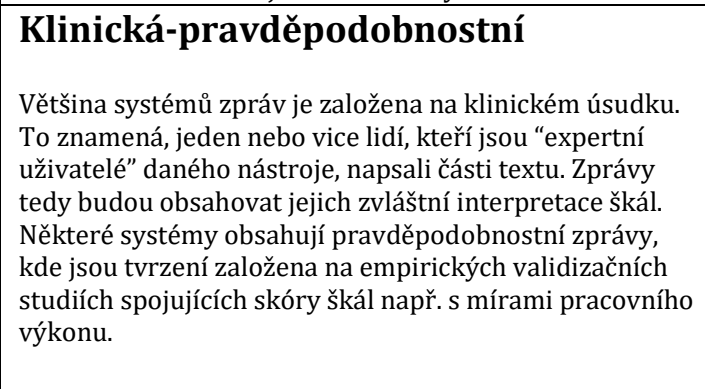 & 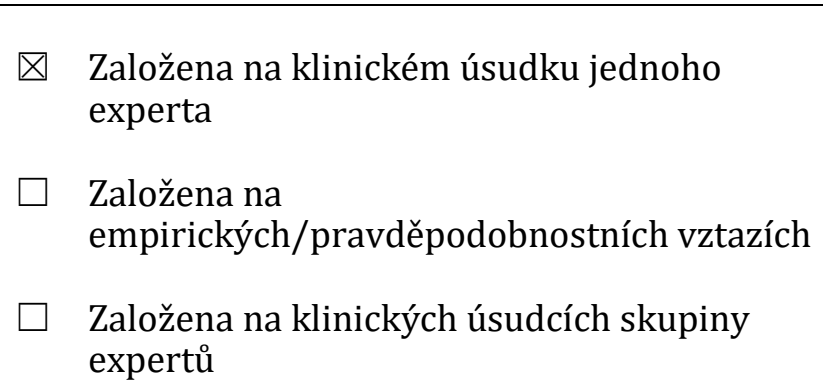 \\
\hline 1.21 .6 & $\begin{array}{l}\text { Modifikovatelnost } \\
\text { Výstup zprávy je často fixní. Ale některé systémy vytvoří } \\
\text { výstup ve formě souboru, který mǔže uživatel dale } \\
\text { zpracovat. }\end{array}$ & $\begin{array}{ll}\square & \begin{array}{l}\text { Nemodifikovatelná (pouze fixní tištěný } \\
\text { výstup) }\end{array} \\
\square & \begin{array}{l}\text { Omezené modifikace (omezené na určité } \\
\text { oblasti, např. pole biografických dat) }\end{array} \\
\square \quad \begin{array}{l}\text { Neomezené modifikace (např. díky př́ístupu } \\
\text { k dokumentu ve Wordu) }\end{array}\end{array}$ \\
\hline 1.21 .7 & 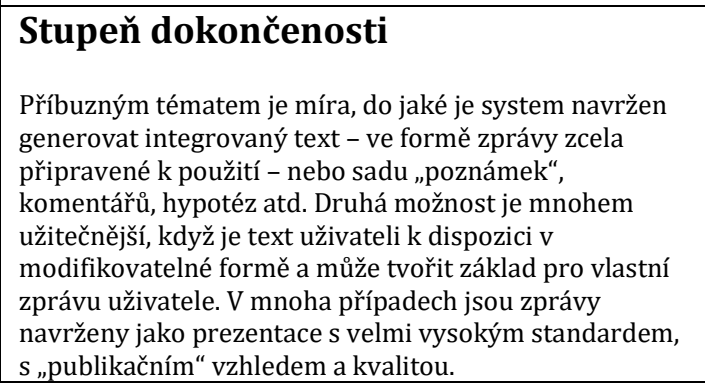 & $\begin{array}{ll}\square & \text { Publikační kvalita } \\
\bigotimes & \text { Kvalita pracovní verze }\end{array}$ \\
\hline
\end{tabular}




\begin{tabular}{|c|c|c|c|}
\hline 1.21 .8 & $\begin{array}{l}\text { Transparence } \\
\text { Systémy se liší svojí otevřeností nebo transparentností } \\
\text { vǔči uživateli. Otevřený system je ten, kde je spojení } \\
\text { mezi skórem škály a textem jasné a jednoznačné. Taková } \\
\text { otevřenost je možná pouze tehdy, když jsou } \\
\text { prezentovány jak texty, tak skóry, a spojení mezi nimi } \\
\text { explicitně uvedeno. Jiné systémy pracují jako "černé } \\
\text { skříňky" a znesnadňují uživateli dát do vztahu skóry škál } \\
\text { a text. }\end{array}$ & $\begin{array}{l}\square \\
\square\end{array}$ & $\begin{array}{l}\text { Jasné spojení mezi skóry konstruktů } \\
\text { a textem } \\
\text { Zatajené spojení mezi konstrukty, skóry } \\
\text { a textem } \\
\text { Směs jasných/zatajených spojení mezi } \\
\text { konstrukty, skóry a textem }\end{array}$ \\
\hline 1.21 .9 & $\begin{array}{l}\text { Styl a tón } \\
\text { Systémy se take liší v míře, do jaké nabízejí čtenáři } \\
\text { zprávy vedení nebo směr. Některé jsou deklarativní „Pan } \\
\text { X je velmi plachý a nebude dobrým prodejcem...". Jiné } \\
\text { jsou navrženy tak, aby nabízely hypotézy nebo vznášely } \\
\text { otázky: „Na základě jeho skórủ na škále Y se pan X zdá } \\
\text { být velmi plachým. Pokud je to tak, mohlo by pro něho } \\
\text { být obtížné pracovat v prostředí prodeje. Je nutné to } \\
\text { v jeho případě dale prozkoumat.” }\end{array}$ & $\begin{array}{l}\square \\
\square \\
\square\end{array}$ & $\begin{array}{l}\text { Direktivní } \\
\text { Hypotetizující } \\
\text { Jiné: Text je na pomezí těchto dvou stylů, } \\
\text { nabízí zejména srovnání s ostatními. }\end{array}$ \\
\hline 1.21 .10 & Zamýšlení př́́jemci & $\begin{array}{l}\square \\
\square \\
\square \\
\square \\
\square\end{array}$ & $\begin{array}{l}\text { Kvalifikovaní uživatelé testu } \\
\text { Osoby kompetentní vytvořit vlastní zprávy. } \\
\text { Kvalifikovaní uživatelé systému } \\
\text { Osoby, které nejsou kompetentní vytvořit samostatně } \\
\text { vlastní zprávy, ale mají trénink potřebný pro používání } \\
\text { zpráv generovaných systémem. } \\
\text { Respondenti testu } \\
\text { Respondent testu zpravidla nemá žádnou předchozí } \\
\text { znalost nástroje ani typu zprávy. } \\
\text { Třetí strany } \\
\text { Např. potenciální zaměstnavatel, rodič vedoucí či } \\
\text { supervizor apod. }\end{array}$ \\
\hline 1.22 & $\begin{array}{l}\text { Nabízejí distributoři službu opravy } \\
\text { a/nebo vývoje počítačových zpráv? }\end{array}$ & $\square$ & $\begin{array}{l}\text { Ano } \\
\mathrm{Ne}\end{array}$ \\
\hline
\end{tabular}

Č́ást 5 :

Nabídka, podmínky a náklady

Tato část definuje, co vydavatel poskytne, komu, za jakých podmínek a za jaké ceny. Definuje podmínky kladené dodavatelem a týkající se toho, kdo smí a kdo nesmí získat materiál nástroje. Pokud jedna z možností neodpovídá podmínkám nabídky, doplňte popis relevantních podmínek.

\begin{tabular}{|l|l|ll|}
\hline 1.23 & Dokumentace poskytovaná & $\bigotimes$ & Uživatelský manuál \\
& distributorem jako součást & $\bigotimes$ & Technický (psychometrický) manuál \\
& testového balíku & $\square$ & Doplňkové technické informace a aktualizace \\
& & (např. lokální normy, lokální validizační studie \\
& & $\begin{array}{l}\text { atd.) } \\
\text { Rozšiřující informace v podobě knih a článků k } \\
\text { tématu }\end{array}$ \\
& $\square \quad$ Kombinace výše uvedených (uved'te) \\
\hline
\end{tabular}




\begin{tabular}{|c|c|c|}
\hline 1.24 & Metody publikace & $\begin{array}{ll}\otimes & \text { Papír } \\
\square & \text { PC - Diskety } \\
\square & \text { PC - CD/ROM } \\
\square & \text { Download z internetu } \\
\square & \text { Živý internet (nástroj pracuje v internetovém } \\
& \text { prohlížeči) } \\
\square & \text { Jiné: }\end{array}$ \\
\hline 1.25 .1 & $\begin{array}{l}\text { Počáteční náklady. } \\
\text { Cena kompletní sady materiálů (všechny manuály a } \\
\text { další material nutný k aspon̆ jedné zkušební } \\
\text { administraci). Kolik uchazečú lze vyšetřovat pomocí } \\
\text { materiálù získaných za počáteční náklady, kde tyto } \\
\text { náklady zahrnují materially pro opakované vyšetření. }\end{array}$ & $\begin{array}{l}\text { Úplný testový soubor stojí } 3500 \text {,- Kč a obsahuje } \\
\text { př́ručku, seznam položek - forma S ( } 5 \mathrm{ks}) \text {, } \\
\text { záznamové listy ( } 30 \mathrm{ks}) \text {, vyhodnocovací listy - } \\
\text { forma S1 ( } 10 \mathrm{ks}) \text {, vyhodnocovacílisty - forma S2 ( } 10 \\
\text { ks) a vyhodnocovací listy - forma S3 (30 ks). }\end{array}$ \\
\hline 1.25 .2 & Opakující se náklady: & $\begin{array}{l}\text { Opakovat se mohou náklady na propisovací } \\
\text { záznamový list, přičemž } 30 \text { ks stojí } 750,- \text { Kč. }\end{array}$ \\
\hline 1.26 .1 & $\begin{array}{l}\text { Ceny za zprávy generované } \\
\text { softwarem nainstalovaným } \\
\text { uživatelem: }\end{array}$ & Cena za jednorázové testování je 400,- Kč vč. DPH \\
\hline 1.26 .2 & $\begin{array}{l}\text { Ceny za vyhotovení zprávy zaslené } \\
\text { prostřednictvím pošty/faxu: }\end{array}$ & $\begin{array}{l}\text { Počítačem generovaná zpráva se nezpoplatňuje } \\
\text { samostatně, její cena je součástí úhrady kreditů za } \\
\text { testování. }\end{array}$ \\
\hline 1.26 .3 & $\begin{array}{l}\text { Ceny za vyhotovení zprávy zaslené } \\
\text { prostřednictvím internetové služby: }\end{array}$ & \\
\hline 1.27 & $\begin{array}{l}\text { Ceny za další služby a zpracování } \\
\text { dat: opravy nebo vývoj } \\
\text { automatických zpráv: }\end{array}$ & \\
\hline 1.28 & 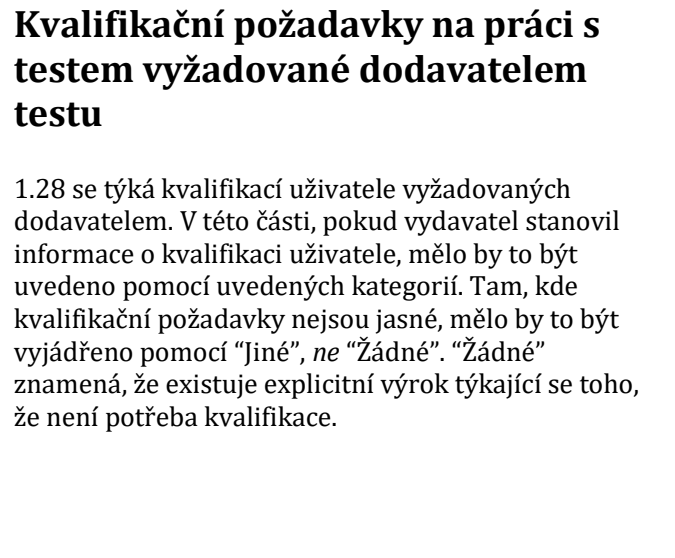 & 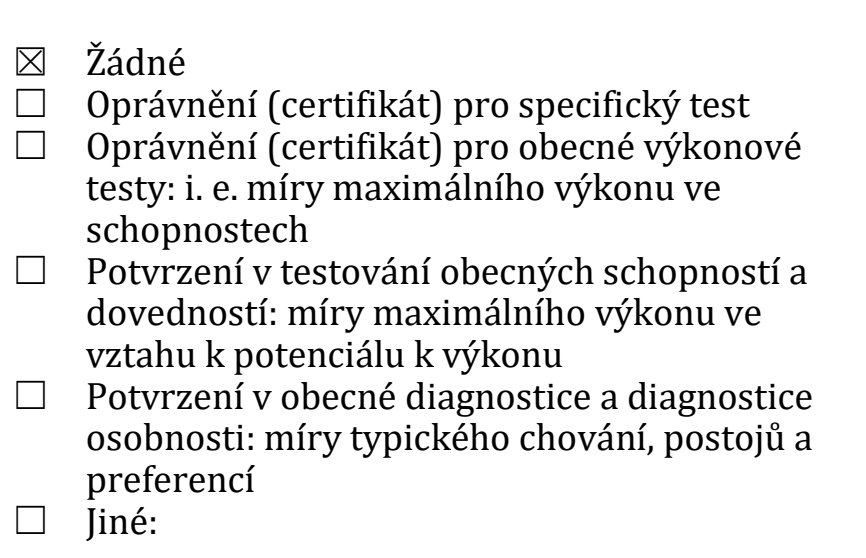 \\
\hline 1.29 & 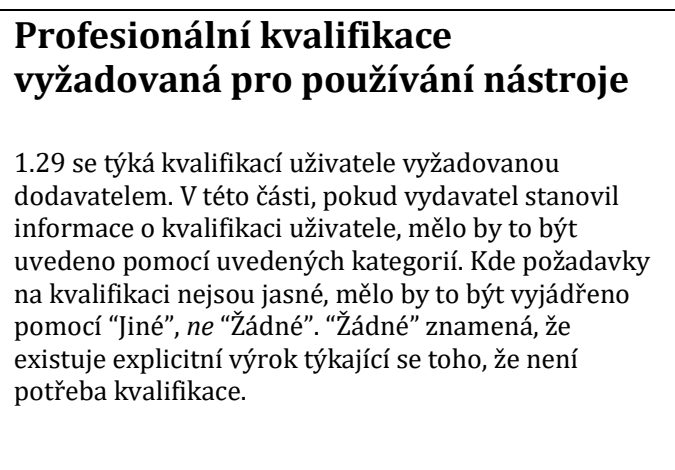 & $\begin{array}{ll}\square & \text { Žádné } \\
\square & \text { Praktický psycholog s kvalifikací v relevantní } \\
& \text { aplikační oblasti } \\
\square & \text { Praktický psycholog } \\
\square & \text { Výzkumný psycholog } \\
\square & \text { Nepsychologický akademický výzkumník } \\
\square & \text { Praktik v relevantních př́buzných profesích } \\
\text { (terapie, medicína, poradenství, vzdělání, } \\
\text { lidské zdroje atd.) } \\
\square \quad \text { Držitel Certifikátu způsobilosti pro testování } \\
\text { v psychologii práce A BPS }\end{array}$ \\
\hline
\end{tabular}




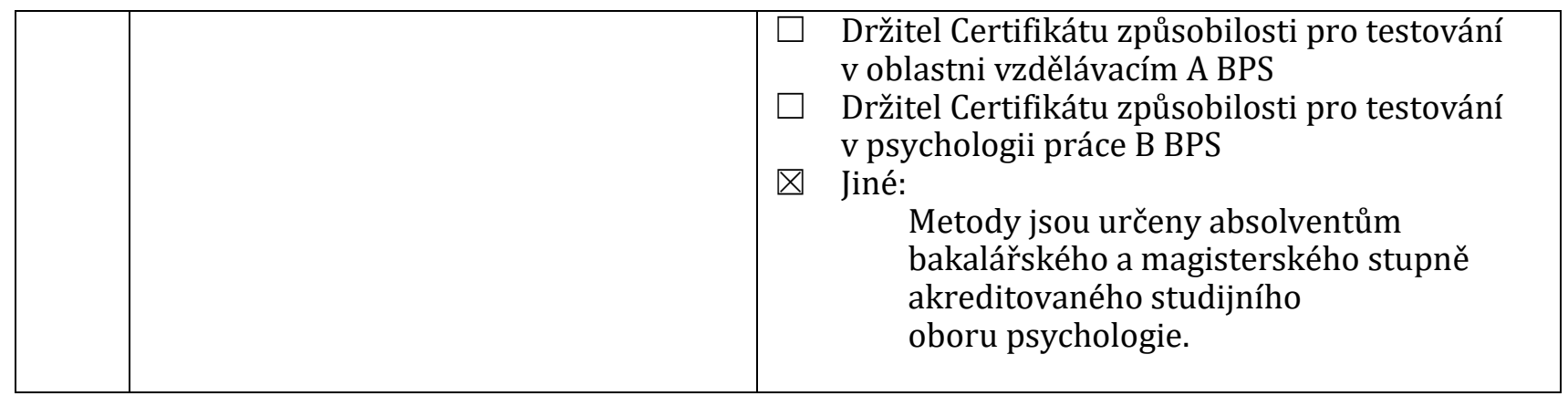

\section{Č́st 6:}

\section{Hodnocení testových materiálů}

\section{Vysvětlení hodnocení}

V následujících částech jsou celková posouzení adekvátnosti informací týkajících se validity, reliability a norem zobrazeny automaticky tučně.

Jakýkoli nástroj $s$ jedním nebo více posouzeními 0 nebo 2 týkajícími se atributů považovaných za kritické pro bezpečné používání nástroje, by neměl být považován za nástroj, který splňuje minimální standardy.

\begin{tabular}{|c|c|c|c|}
\hline $\begin{array}{l}\text { Vstup na posuzovacím } \\
\text { formuláři }\end{array}$ & $\begin{array}{l}\text { Posouzení podle } \\
\text { standardů EFPA }\end{array}$ & $\begin{array}{c}\text { Reprezentace recenze } v \\
\mathrm{UK}\end{array}$ & Vysvětlení \\
\hline [n/a] & [n/a ] & [n/a ] & $\begin{array}{l}\text { Tento atribut není u tohoto } \\
\text { nástroje použitelný }\end{array}$ \\
\hline $\mathbf{0}$ & {$[-]$} & [None ] & $\begin{array}{c}\text { Není možné posoudit jako } \\
\text { ne nebo nedostatek } \\
\text { poskytnutých informací }\end{array}$ \\
\hline 1 & {$[-1]$} & {$\left[\begin{array}{ll}* & ]\end{array}\right.$} & Neadekvátní \\
\hline 2 & & {$\left[\begin{array}{ll}* * & ]\end{array}\right.$} & NYNÍ NEPOUŽÍVÁNO \\
\hline 3 & {$\left[\begin{array}{ll}0 & 0\end{array}\right]$} & {$\left[\begin{array}{ll}* * * & ]\end{array}\right.$} & Adekvátní nebo přiměřený \\
\hline 4 & [ 1 ] & {$\left[{ }^{* * * *}\right]$} & Dobrý \\
\hline \multirow[t]{2}{*}{5} & [ 2 ] & {$[* * * * *]$} & Vynikající \\
\hline & & $\begin{array}{c}\text { [N.r.i.o.r] }{ }^{*} \text { (pouze pro } \\
\text { aktualizace) }\end{array}$ & $\begin{array}{l}\text { Položka nebyla v původní } \\
\text { recenzi posuzována }\end{array}$ \\
\hline
\end{tabular}

V této části má být provedeno více hodnocení různých aspektů nebo atributů dokumentace dodávané s nástrojem (nebo balíkem). Termín „dokumentace“ byl vybrán, aby pokrýval všechny ty materiály dodávané s nástrojem nebo snadno dostupné kvalifikovanému uživateli: např. manual administrátora; technické příručky; brožury s normami; dodatky k manuálu; aktualizace od vydavatelů/dodavatelů atd.

Položky mají být posuzovány n/a nebo 0 až 5 (poloviční rating je přijatelný)

Rating

\begin{tabular}{|l|l|l|}
\hline $\begin{array}{l}\text { Kvalita vysvětlení principů, prezentace a kvalita poskytnuté informace: } \\
\text { Tento celkový rating se získá použitím posouzení založeného na ratinzích daných pro položky 2.1-2.8) }\end{array}$ & $\mathbf{4}$ \\
\hline 2.1 & $\begin{array}{l}\text { Celkový rating kvality vysvětlení principů: (Tento celkový rating se získá použitím } \\
\text { posouzení založeného na hodnotách ratingů daných pro položky 2.1.1 - 2.1.5) }\end{array}$ & $\mathbf{3}$ \\
\hline 2.1 .1 & i) Teoretické základy konstruktů: & 3 \\
\hline 2.1 .2 & ii) Procedura vývoje testu: & 3 \\
\hline 2.1 .3 & iii) Důkladnost analýz položek a model analýzy položek: & 0 \\
\hline
\end{tabular}




\begin{tabular}{|c|c|c|}
\hline 2.1 .4 & iv) Vysvětlení obsahové validity: & 4 \\
\hline 2.1 .5 & v) Souhrn relevantního výzkumu: & 3 \\
\hline 2.2 & $\begin{array}{l}\text { Adekvátnost dokumentace dostupné uživateli (uživatelské a technické } \\
\text { manuály, dodatky týkající se norem atd.): (Tento celkový rating se získá použitím } \\
\text { posouzení založeného na hodnotách ratingů daných pro položky } 2.2 .1-2.2 .6 \text { ) } \\
\text { Pro část } 2.2 \text { jsou stanoveny následující „měřítka“ pro rating „vynikajíci““ (5). Pozornost je zde zaměřena } \\
\text { na kvalitu pokrytí poskytnutého v dokumentaci dostupné kvalifikovaným uživatelům. Všimněte si, že část } \\
2.2 \text { se týká úplnosti a jasnosti dokumentace dostupné uživateli (uživatelské a technické manually, doadtky } \\
\text { k normám atd.) v pojmech pokrytí a vysvětlení. V pojmech kvality nástroje, jak ji dosvědčuje dokumentace, } \\
\text { jsou rozpracovány oblasti v této části pod čísly: } 2.1,2.3,2.9,2.10 \text { a } 2.11 \text {. }\end{array}$ & 4 \\
\hline 2.2 .1 & $\begin{array}{l}\text { Principy: [viz 2.1] } \\
\text { Dobře argumentovaný a jasně prezentovaný popis toho, co má podle návrhu měřit a proč byl zkonstruován } \\
\text { tak, jak je. }\end{array}$ & 3 \\
\hline 2.2 .2 & $\begin{array}{l}\text { Vývoj: } \\
\text { Úplné detaily týkající se zdrojů položek, pilotáže, analýz položek, srovnávacích studií a změn prováděných v } \\
\text { průběhu vývojovyych pokusŭ. }\end{array}$ & 3 \\
\hline 2.2 .3 & $\begin{array}{l}\text { Standardizace: } \\
\text { Jasné a detailní informace poskytnuté o velikostech a zdrojích standardizačního souboru a standardizační } \\
\text { proceduře. }\end{array}$ & 4 \\
\hline 2.2 .4 & $\begin{array}{l}\text { Normy: } \\
\text { Jasné a detailní informace poskytnuté o velikostech a zdrojích normalizačních skupin, podmínkách vyšetření } \\
\text { atd. }\end{array}$ & 4 \\
\hline 2.2 .5 & $\begin{array}{l}\text { Reliabilita: } \\
\text { Dobré vysvětlení reliability a široký rozsah měr vnitřní konsistence a retestu spolu s vysvětlením jejich } \\
\text { relevance a zobecnitelnosti nástroje vyšetření. }\end{array}$ & 4 \\
\hline 2.2 .6 & $\begin{array}{l}\text { Validita: } \\
\text { Dobré vysvětlení validity spolu s širokou škálou studií jasně a poctivě popsaných. }\end{array}$ & 3 \\
\hline 2.3 & $\begin{array}{l}\text { Kvalita procedurálních instrukcí poskytnutých uživateli: (Tento celkový rating se } \\
\text { získá s použitím posouzení na základě hodnot ratingů daných pro položky } 2.3 .1-2.3 .7 \text { ) }\end{array}$ & 5 \\
\hline 2.3 .1 & $\begin{array}{l}\text { Pro administraci testu: } \\
\text { Poskytnutá jasná a detailní vysvětlení a procedurální průvodce krok za krokem spolu s dobrými radami } \\
\text { týkajícícmi se otázek uchazeču a problémových situací. }\end{array}$ & 5 \\
\hline 2.3 .2 & $\begin{array}{l}\text { Pro skórování testu, normy atd.: } \\
\text { Poskytnuté jasné a detailní informace spolu s popsanými kontrolami pro vyhnutí se možným chybám } \\
\text { skórování. }\end{array}$ & 5 \\
\hline 2.3 .3 & $\begin{array}{l}\text { Pro interpretaci a vytváření zpráv: } \\
\text { Detailní doporučení týkající se interpretace různých skórů, chápání normativních měr a zacházení se vztahy } \\
\text { mezi rưznými škálami, s množstvím ilustrativních příkladů a př́ipadových studií. }\end{array}$ & 5 \\
\hline 2.3 .4 & $\begin{array}{l}\text { Pro poskytnutí zpětné vazby a debriefingu respondentům testu a dalším: } \\
\text { Detailní doporučení, jak prezentovat zpětnou vazbu uchazečủm. }\end{array}$ & 5 \\
\hline 2.3 .5 & $\begin{array}{l}\text { Pro poskytování dobrých praktických témat týkajících se poctivosti a } \\
\text { zkreslení: } \\
\text { Uvedení detailních informací o studiích sexuálního a etnického zkreslení s relevantními varováními týkajícími } \\
\text { se používání a zobecňování validit. }\end{array}$ & 4 \\
\hline 2.3 .6 & $\begin{array}{l}\text { Omezení používání: } \\
\text { Jasné popisy, kdo by měl a kdo by neměl být vyšetřován spolu s dobře vysvětlenými odůvod něními těchto } \\
\text { omezení (napřs. typy nezpůsobilostí, požadované úrovně gramotnosti atd.). }\end{array}$ & 5 \\
\hline 2.3 .7 & $\begin{array}{l}\text { Reference a podpůrné materiály: } \\
\text { Detailní odkazy na relevantní podpůrnou akademickou literature a křížové odkazy na další příbuzné } \\
\text { materially týkající se diagnostických nástrojü. }\end{array}$ & 5 \\
\hline \multicolumn{2}{|r|}{$\begin{array}{l}\text { Kvalita materiálů: } \\
\text { (Tento celkový rating se získá použitím posouzení založeného na hodnotách ratingů pro položky } 2.4-2.8 \text { ) }\end{array}$} & 4,5 \\
\hline 2.4 & $\begin{array}{l}\text { VŠeobecná kvalita materiálů testu } \\
\text { (testové brožury, odpověd'ové archy, testové objekty, software atd.): }\end{array}$ & 5 \\
\hline 2.5 & Kvalita lokální adaptace testu (pokud byl test přeložen a adaptován do místního jazyka): & 5 \\
\hline 2.6 & Snadnost, s jakou může respondent testu porozumět úkolu: & 5 \\
\hline 2.7 & $\begin{array}{l}\text { Snadnost, s jakou mohou být respondentem testu tvořeny reakce nebo } \\
\text { odpovědi: }\end{array}$ & 4 \\
\hline 2.8 & Kvalita položek: & 4 \\
\hline
\end{tabular}




\section{Recenzentovy komentáře týkající se dokumentace:}

(komentáře principů, designu, vývoje testu a jeho přijatelnosti)

\section{Standardizace české verze}

Inventář byl do češtiny přeložen nezávisle na sobě třemi osobami - psychologem, profesionálním překladatelem a jedním z autorů příručky. Ti pak na základě vzájemné diskuse dospěli k závěrečnému znění položek. Problémy s překladem se objevily zejména $\mathrm{v}$ případě položek postihujících způsoby chování a životní styl obvyklý v USA a vztahující se $\mathrm{k}$ tamní kultuře (jak s nimi bylo naloženo již ovšem není zmíněno). Položky pak byly profesionálním překladatelem zpět přeloženy do angličtiny a revidovány rodilým mluvčím. $\mathrm{V}$ tomto znění byly odeslány autorům metody, kteří se k nim vyjádřili a doporučili dílčí úpravy v případech, v nichž došlo při překladu podle jejich názoru k posunu významu. Na základě těchto připomínek byla provedena revize položek a byla vytvořena závěrečná verze inventáře. Inventář NEO-PI-3 obsahuje položky v již revidovaném znění z roku 2014, včetně změny formulací v některých položkách.

\section{Část 7:}

\section{Hodnocení norem, reliability a validity}

\begin{tabular}{|l|l|}
\hline $\begin{array}{l}\text { Hodnožky mají být posuzovány n/a nebo } 0 \text { až } 5 \text { (jsou přijatelné poloviční ratingy) } \\
\text { (Tento celkoví technickích se získá použitím posouzení založeného na hodnotách ratingů daných pro položky } 2.9-2.11 \text { ) }\end{array}$ \\
\hline
\end{tabular}

\section{Informace o normách nebo referenční skupině}

\begin{tabular}{|c|c|c|}
\hline 2.9 & Celková adekvátnost: & 4 \\
\hline 2.9 .1 & 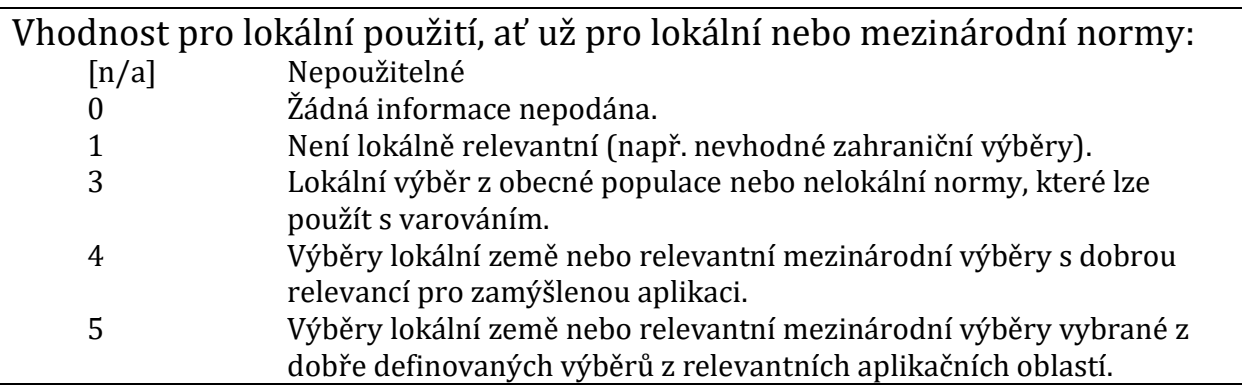 & 4 \\
\hline 2.9 .2 & $\begin{array}{ll}\begin{array}{l}\text { Vhodnost pro zamýšlené aplikace: } \\
{[\mathrm{n} / \mathrm{a}]}\end{array} & \text { Nepoužitelné } \\
0 & \text { Žádná informace nepodána. } \\
1 & \text { Norma nebo normy nejsou adekvátní pro zamýšlené aplikace. } \\
3 & \begin{array}{l}\text { Adekvátní normy pro obecnou populaci a/nebo rozmezí normativních } \\
\text { tabulek. }\end{array} \\
4 & \begin{array}{l}\text { Dobré rozmezí normativních tabulek. } \\
5\end{array} \\
& \begin{array}{l}\text { Vynikající rozmezí výběrově relevantních norem vztahujících se k věku } \\
\text { a pohlaví, s informacemi o dalších rozdílech v rámci skupin (např. } \\
\text { směs etnických skupin). }\end{array}\end{array}$ & 3 \\
\hline
\end{tabular}




\begin{tabular}{|c|c|c|c|}
\hline 2.9 .3 & $\begin{array}{c}\text { Velikosti výběrů: } \\
\text { [n/a] } \\
0 \\
1 \\
3 \\
4 \\
5\end{array}$ & $\begin{array}{l}\text { Nepoužitelné } \\
\text { Žádná informace nepodána. } \\
\text { Neadekvátní výběry (např. méně než 150). } \\
\text { Adekvátní výběry (např. 150-300). } \\
\text { Velké výběry (např. 300-1000). } \\
\text { Velmi velké výběry (např. 1000+). }\end{array}$ & 5 \\
\hline 2.9 .4 & $\begin{array}{c}\text { Procedury použit } \\
\text { (vyberte jednu a ohod } \\
\square \\
\square \\
\square\end{array}$ & $\begin{array}{l}\text { tí při výběru souboru: } \\
\text { dnottee kvalitu použitého postupu) } \\
\text { Žádná informace neposkytnuta } \\
\text { Reprezentativní populaci [sumarizujte kritéria] } \\
\text { Nahodilá } \\
\text { Náhodná }\end{array}$ & 4 \\
\hline 2.9 .5 & $\begin{array}{l}\text { Kvalita informací } \\
\text { vlivech věku, rod } \\
\text { [n/a] } \\
0 \\
1 \\
3 \\
4 \\
5\end{array}$ & $\begin{array}{l}\text { í poskytnutých o minoritní/chráněné skupině, rozdílech, } \\
\text { du atd.: } \\
\text { Nepoužitelné } \\
\text { Žádná informace nepodána. } \\
\text { Neadekvátní informace. } \\
\text { Adekvátní obecné informace s minimální analýzou. } \\
\text { Dobré popisy a analýzy skupin a rozdílü } \\
\text { Vynikajíí série analýz a diskuse o relevantních tématech vztahujících } \\
\text { se k použití a interpretaci. }\end{array}$ & 3 \\
\hline \multicolumn{4}{|c|}{$\begin{array}{l}\text { 2.9.6 Komentáře recenzentů k normám: Stručná zpráva o normách a jejich historii, včetně informací o doporučeních } \\
\text { učiněných vydavatelem/autorem pro aktualizaci norem obvyklým zpủsobem. }\end{array}$} \\
\hline \multicolumn{4}{|c|}{ 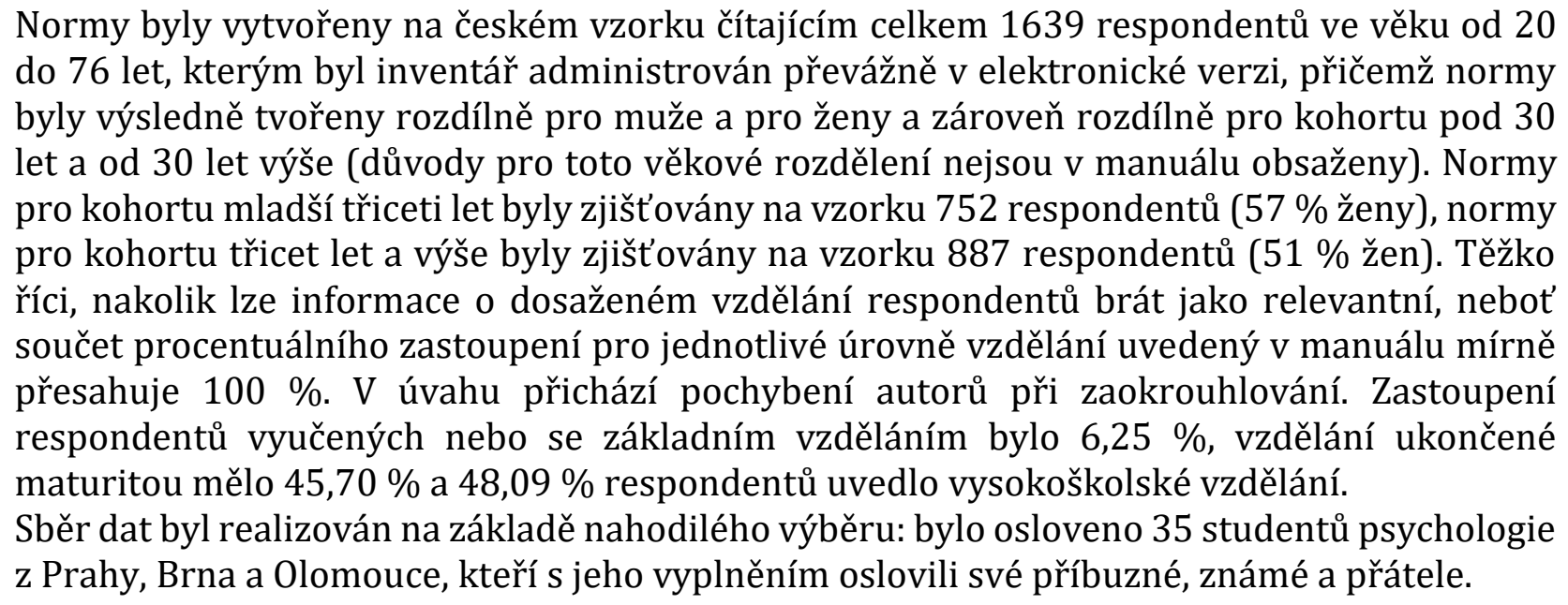 } \\
\hline
\end{tabular}

\section{Validita}

\begin{tabular}{|l|l|l|}
\hline 2.10 & $\begin{array}{l}\text { Celková adekvátnost: (Tento celkový rating se získá na základě posouzení hodnot ratingů } \\
\text { daných v položkách } 2.10 .1-2.10 .2 .4 . \text { Neprůměrujte pouze čísla, abyste získali celkový rating. } \\
\text { Obvykle bude roven bud' konstruktové validitě nebo validitě vztahující se ke kritériu, podle } \\
\text { toho, která z nich je vyšší.) }\end{array}$ & $\begin{array}{l}\mathbf{3} \\
\text { Konstruktová validita - celková adekvátnost } \\
\text { (Tento celkový rating se získá na základě posouzení hodnot ratingů daných v položkách } \\
2.10 .1 .2-2.10 .1 .6 . \text { Neprưměrujte pouze čísla, abyste tento celkový rating získali.) }\end{array}$ \\
\hline
\end{tabular}




\begin{tabular}{|c|c|c|c|}
\hline 2.10.1.1 & $\begin{array}{c}\text { Použité p } \\
\square \\
\square \\
\square \\
\square \\
\square \\
\square \\
\square \\
\square \\
\square\end{array}$ & $\begin{array}{l}\text { lány: (zatrhněte tolik, kolik je jich použitelných) } \\
\text { Žádná informace nepodána } \\
\text { Korelace s dalšími nástroji a výkonovými kritérii } \\
\text { Vnitroškálový (korelace položky se zbytkem) } \\
\text { Rozdíly mezi skupinami } \\
\text { Matice mnoha rysů a mnoha metod (MTMM) } \\
\text { Explorační faktorová analýza } \\
\text { Konfirmační faktorová analýza } \\
\text { Experimentální plány } \\
\text { Jiné: validita jako míra shody posuzovatelů }\end{array}$ & \\
\hline 2.10 .1 .2 & $\begin{array}{c}\text { Velikosti } \\
0 \\
1 \\
3 \\
4 \\
5 \\
\end{array}$ & $\begin{array}{l}\text { výběrů: } \\
\text { Žádná informace neposkytnuta. } \\
\text { Jedna neadekvátní studie (např. velikost výběru menšś než 100). } \\
\text { Jedna adekvátní studie (např. velikost výběru 100-200). } \\
\text { Více než jedna adekvátní nebo velká studie. } \\
\text { Dobrá série adekvátních až rozsáhlých studií. }\end{array}$ & 4 \\
\hline 2.10 .1 .3 & 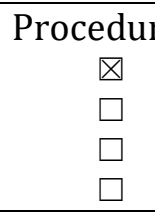 & $\begin{array}{l}\text { ra výběru souboru: (vyberte jednu) } \\
\text { Žadná informace neposkytnuta } \\
\text { Reprezentativní vůči populaci [sumarizujte kritéria] } \\
\text { Nahodilá } \\
\text { Náhodná }\end{array}$ & \\
\hline 2.10 .1 .4 & $\begin{array}{c}\text { Medián a } \\
0 \\
1 \\
3 \\
4 \\
5\end{array}$ & $\begin{array}{l}\text { rozsah korelací mezi testem a dalšími podobnými testy: } \\
\text { Žádná informace neposkytnuta. } \\
\text { Neadekvátní }(\mathrm{r}<0.55) \text {. } \\
\text { Adekvátní }(0.55<\mathrm{r}<0.65) \text {. } \\
\text { Dobrý }(0.65<\mathrm{r}<0.75) \text {. } \\
\text { Vynikajíí }(\mathrm{r}>0.75)\end{array}$ & 3 \\
\hline 2.10 .1 .5 & $\begin{array}{c}\text { Kvalita n } \\
0 \\
1 \\
3 \\
4 \\
5\end{array}$ & $\begin{array}{l}\text { ástrojů jako kritérií nebo markerů: } \\
\text { Žádná informace neposkytnuta. } \\
\text { Poskytnuta neadekvátní informace. } \\
\text { Adekvátní kvalita. } \\
\text { Dobrá kvalita. } \\
\text { Vynikající kvalita s širokým rozsahem relevantních markerů pro } \\
\text { konvergentní a divergentní validizaci. } \\
\end{array}$ & 3 \\
\hline 2.10 .1 .6 & $\begin{array}{r}\text { Analýzy } \\
{[\mathrm{N} / \mathrm{A}} \\
0-5 \\
\end{array}$ & $\begin{array}{l}\text { diferenciálního fungování položek (DIF): } \\
\text { Nepoužitelné } \\
\text { hodnocení kvality DIF analýzy }\end{array}$ & 0 \\
\hline 2.10 .2 & $\begin{array}{l}\text { Validita } \\
\text { (Tento celkc } \\
2.11 .1-2.10\end{array}$ & $\begin{array}{l}\text { vztahující se ke kritériu - celková adekvátnost } \\
\text { vý rating se získá na základě posouzení hodnot ratingů daných v položkách } \\
\text { v.2.4. Neprüměrujte pouze čísla, abyste získali celkový rating.) }\end{array}$ & 3 \\
\hline 2.10 .2 .1 & $\begin{array}{c}\text { Popis po } \\
\square \\
\square \\
\square\end{array}$ & $\begin{array}{l}\text { užitých kritérií a charakteristik populací: (zatrhněte tolik, kolik je pou } \\
\text { Souběžná } \\
\text { Prediktivní } \\
\text { Postdiktivní }\end{array}$ & \\
\hline 2.10 .2 .2 & $\begin{array}{c}\text { Velikost } \\
0 \\
1 \\
3 \\
4 \\
5\end{array}$ & $\begin{array}{l}\text { ti výběrů: } \\
\text { Žádná informace neposkytnuta. } \\
\text { Jedna neadekvátní studie (napřr. velikost výběru menší než 100). } \\
\text { Jedna adekvátní studie (napřr. velikost výběru 100-200). } \\
\text { Jedna velká nebo vice než jedna adekvátně rozsáhlá studie. } \\
\text { Dobrá série adekvátních až rozsáhlých studií. }\end{array}$ & 0 \\
\hline 2.10 .2 .3 & $\begin{array}{c}\text { Procedur } \\
\text { (vyberte je } \\
\quad \square \\
\square \\
\square \\
\square \\
\square\end{array}$ & $\begin{array}{l}\text { ra výběru souboru: } \\
\text { dnu) } \\
\text { Ž́ádná informace neposkytnuta } \\
\text { Účelná nebo reprezentativní } \\
\text { Nahodilá } \\
\text { Náhodná } \\
\end{array}$ & \\
\hline 2.10 .2 .4 & $\begin{array}{c}\text { Medián a } \\
0 \\
1 \\
3 \\
4 \\
5\end{array}$ & $\begin{array}{l}\text { rozsah korelací mezi testem a kritérii: } \\
\text { Žádná informace neposkytnuta. } \\
\text { Neadekvátní (napřr. } \mathrm{r}<0.2 \text { ). } \\
\text { Adekvátní (napřr. } 0.2<\mathrm{r}<0.35 \text { ). } \\
\text { Dobrý (napřr. } 0.35<\mathrm{r}<0.50) . \\
\text { Vynikající (např. } \mathrm{r}>0.50 \text { ) }\end{array}$ & 0 \\
\hline
\end{tabular}




\subsubsection{Komentáře recenzenta týkající se validity:}

\section{Validita}

Validita NEO-PI-3 je v manuálu posuzovaná zejména z hlediska vztahů rysů v rámci příslušné teorie, tedy z hlediska konstruktové validity. Vzhledem $\mathrm{k}$ tomu, že ani v České republice a ani v USA nejsou k dispozici údaje o validitě NEO-PI-3 (s výjimkou studie Hřebíčkové a Jelínka z roku 2019, která zjišt'ovala faktorovou strukturu NEO-PI-3, viz podkapitola Faktorová struktura), byly pro validizaci použity údaje z validity jiných inventářů (např. NEO-PI-R, NEOFFI). NEO-PI-R a NEO-PI-3 mají velmi podobnou strukturu, lze proto předpokládat, že i korelace $s$ jinými psychologickými nástroje by v př́ípadě NEO-PI-3 byly podobné. NEO-FFI je zase zkrácenou verzí NEO-PI-R, která dosahuje relativně dobré shody s NEO-PI-3 a kdy průměrná hodnota společného rozptylu napříč škálami je 83,3 \% (Hřebíčková \& Jelínek, 2019).

Posuzování validity se drží teoretického rámce, ze kterého NEO inventáře vycházejí, tj. faktorový model analýzy slov používaných $\mathrm{v}$ přirozeném jazyce pro popis osobnosti. Validizace byla založena na korelaci mezi sebeposouzením na škálách NEO a sebeposouzením podle adjektiv reprezentujících pětifaktorovou strukturu osobnosti v češtině. Korelace mezi škálami NEO-FFI a sebeposouzením podle adjektiv byla od 0,17 v případě otevřenosti vůči zkušenosti, po $0,72 \mathrm{v}$ případě svědomitosti. Nízká korelace $\mathrm{v}$ případě otevřenosti vůči zkušenosti je podle autorů validizační studie důsledkem odlišného obsahu českého faktoru a faktoru v NEO inventářích. Uspokojivější výsledky přinesla validizační studie Hřebíčkové (2011, cit. podle manuálu) o korelacích NEO-PI-R pro sebeposouzení a posouzení někým jiným s Inventářem přídavným jmen (IPJ-R), tj. se škálami adjektiv vybraných jako markery pětifaktorové struktury z lexikální analýzy. Korelace se v tomto případě pohybovala od 0,36 $\mathrm{v}$ případě přívětivosti po $0,81 \mathrm{v}$ případě svědomitosti. Celkově $\mathrm{z}$ validizačních studií vyplynulo, že nejvíce se od faktoru NEO inventářů s inventáři adjektiv (lexikálního faktoru) odlišuje otevřenost vůči zkušenosti.

Posouzení celkové validity metody je poměrně obtížné, jelikož různé subškály dosahují různě vysokých korelací. Pokud ovšem pomineme nízkou korelaci mezi NEO-FFI a sebeposouzením podle adjektiv z důvodu odlišného obsahu českého faktoru a faktoru NEO (což je dostatečně dobrý důvod, pro který takto nízkou korelaci pro celkové hodnocení validity nebrat v potaz), dosahují korelace obstojných až dobrých výsledkủ. Velikost těchto korelací můžeme podle našeho názoru považovat za jeden z důkazů podporující celkovou validitu metody.

Dále se posuzování validity soustředí okolo shody posuzovatelů na škále NEO-PI-R, a to jak mezi sebeposouzením a posouzením někým jiným (self-other agreement), tak i okolo míry shody při posouzení jednoho člověka dvěma jinými lidmi (other-other agreement). Tyto shody jsou pro validitu metody velmi relevantní, jelikož teorie stojící za metodou předpokládá, že základních 5 rysů osobnosti je vrozených, majících neurobiologické koreláty (Costa \& McCrae, 2008). Pokud metoda skutečně popisuje rysy osobnosti, které se objektivně projevují a jsou poměrně nezávislé na situačním kontextu, měly by vykazovat poměrně vysokou míru shody mezi sebeposouzením a posouzením osobou, která je cílené osobě blízká. Průměrná míra shody mezi posuzovateli byla $\mathrm{r}=0,56 \mathrm{u}$ hlavních škál, vyšší než $\mathrm{v}$ případě ruské či americké verze. Na úrovni jednotlivých subškál dosahovala míra shody od 0,33 do 0,62 s průměrnou korelací 0,48 . Medián korelace mezi sebeposouzením a posouzením partnerem dosahoval napříč kulturami hodnot od 0,42 pro svědomitost do 0,57 pro extraverzi. Celkově se medián míry shody pro sebeposouzení a posouzení jiným (partnerem, známým, rodinným příslušníkem) a posouzení dvěma třetími osobami pohyboval od 0,40 pro přívětivost po 0,45 pro extraverzi (McCrae a kol., 2004). Obecně nejvyšších hodnot dosahovala extraverze, ve výjimečných případech až korelace okolo 0,70 (sebeposouzení a posouzení jiným), nejnižších zase př́ivětivost a otevřenost ke zkušenostem, někdy až 0,27. 
Zhodnocení těchto hodnot ve smyslu důkazů o validitě metody je těžké posoudit. Tvrzení, že shoda mezi posuzovateli představuje důkaz o určité objektivitě rysů osobnosti platí pouze za předpokladu, že jsou lidé opravdu schopni tyto projevy rysů v chování druhých rozpoznat. John a Robins (cit. podle Szarota, Zawadzki, \& Strelau, 2002) uvedli seznam podmínek na kterých závisí míra shody: 1) posuzovaný rys osobnosti (obecně se ukazuje, že rysy, které většina autorů považuje za temperamentové (tj. extraverze a neuroticismus), dosahují větší míry shody), 2) pozorovatelnost daného rysu, 3) sociální žádoucnost daného rysu, 4) míra blízkosti mezi osobami, 5) schopnost posouzení dané osoby (např. ženy dosahují vyšší shody). Míra shody však ještě nemusí znamenat objektivitu, jelikož sebeposouzení nemusí být spolehlivým zdrojem informací. Mezi základní zkreslení patří sebeprezentace, sebeklamání (self-deception), sociální žádoucnost. Některé položky mohou být obtížné na posouzení (např. nevytahuji se) nebo mohou být hodnoceny správně pouze ostatními, např. v případě, kdy člověk naprosto souhlasí s tím, že je skromná osoba, vypovídá to spíše o jeho neskromnosti. Druhou možností je popř́ít daný rys, což by v tomto př́ípadě o skromnosti vypovídalo více (Hofstee, cit. podle Szarota, Zawadzki \& Strelau, 2002). Z toho vyplývá, že jako důkaz o objektivitě rysů považujeme korelaci dvou zdrojů, které podléhají určitým zkreslením. Korelace mezi těmito zdroji se neukazuje jako extrémně nízká, ani extrémně vysoká. Na druhou stranu se př́liš vysoká korelace ani nedá očekávat, jelikož obě posouzení vycházejí z odlišných pozic a podléhají odlišným zkreslením. Podle nás míra shody přispívá k celkovým důkazům o validitě rysů této metody.

Konvergentní a divergentní validita byla ověřována pomocí multi-trait-multi-method (MTMM) matice, kde byla zaznamenána korelace NEO-PI-R, neverbálního obrázkového testu, který by měl odpovídat vlastnostem obsaženým v pětifaktorovém modelu, a IPJ-R (Inventář př́ídavných jmen). Inventáře NEO-PI-R a IPJ-R byly použity jak pro sebeposouzení, tak pro posouzení někým jiným. Validita byla rovněž ověřována MTMM maticí pro inventář NEO-FFI a dá se předpokládat, že tyto závěry budou pro zjištění validity rovněž směrodatné.

V MTMM byly korelační koeficienty v diagonálách vždy vyšší než korelační koeficienty mimo diagonály ( $\mathrm{v}$ diagonálách nabývaly korelační koeficienty hodnot od 0,20 do 0,93), medián těchto hodnot je 0,47 . Nejnižší korelace 0,20 byla zjištěna $v$ případě škály svědomitost mezi NEO-FFI pro posouzení někým jiným a obrázkovým testem. Důkazy o diskriminační validitě metody přinášejí nízké korelační koeficienty (od 0,00 do 0,36), které se nacházejí mimo diagonály.

Co se mediánu diagonál týče, je nutno podotknout, že může být nadhodnocován korelací mezi testy NEO-PI-R a NEO-FFI, které jsou si velmi podobné (viz výše). Na druhou stranu můžou jeho hodnotu naopak podhodnocovat korelace mezi škálami IPJ-R a obrázkovým testem, což pro validitu metody NEO-PI-3 není nijak relevantní.

Specificky jsme tedy dále zjišt’ovali medián korelací v př́́padě jednotlivých škál mezi NEO-PI$\mathrm{R}$ a IPJ-R, který byl $\mathrm{r}=0,78$ pro sebeposouzení, tedy poměrně vysoký. Mezi NEO-PI-R a obrázkovým testem byl medián korelací pro jednotlivé škály $r=0,53$, rovněž pro sebeposouzení. Takováto úroveň se dá hodnotit jako adekvátní až dobrá.

Tyto informace přinášejí důkazy o konstruktové validitě metody, nebot' nejvyšší korelace v MTMM matici dosahují tytéž rysy měřené jinými metodami. Korelace mezi nimi, a tedy i důkazy o konstruktové validitě, by se daly považovat za uspokojivé.

V neposlední řadě je uvedena validizační studie z prostředí brněnských gymnázií, kde na kohortě ve věku 11-13 let bylo zjištěna korelace s Eysenckovou škálou B-J.E.P.I. zjišt'ující míru neuroticismu, extraverze a psychoticismu. Korelace se pohybuje od - 0,49 (psychoticismus přívětivost) po 0,75 (extraverze - extraverze). 
Kriteriální validita byla ověřována na základě predikce určitého kritéria. Bylo zjištěno, že neuroticismus je prediktorem akulturačního stresu (např́iklad u českých Vietnamců) (Hřebíčková \& Chvojková, cit. podle manuálu, 2016). Prediktorem rasových a jiných předsudků je nízká míra otevřenosti vůči zkušenosti a přívětivostí (oboje $r=-0,49$ ) (Ekehammar \& Akrami, 2007), souvislost byla nalezena mezi přívětivostí a tendencí odpouštět druhým $(\mathrm{r}=0,50)$, neuroticismus souvisí negativně s tendencí odpouštět sám sobě ( $r=-0,62$ ) (Ross, Kendall, Matters, Wrobel, \& Rye, 2004). Dále svědomitost negativně souvisí s absencí ve škole (reportovanou jak učitelem, tak studentem) a se studijním průměrem (GPA). Korelace $v$ tomto prŕṕpadě byla $r=0,35 \mathrm{v}$ případě GPA, resp. $r=0,34 \mathrm{v}$ případě docházky (Conard, 2006; Farsides \& Woodfield, 2003). Jednotlivé škály a subškály predikují také specifické projevy chování (Paunonen \& Ashton, 2001). Např. podškály altruismus, upřímnost, jemnocit, důvěra a skromnost korelovaly společně s mírou ochoty půjčovat peníze $(\mathrm{r}=0,48)$. Míra, $\mathrm{s}$ jakou studenti navštěvují party korelovala společně s hlavními škálami $(\mathrm{r}=$ 0,43). Specifičtější způsoby chování (např. nakupování losů v loterii, pravidelní cvičení) korelují se škálami slabě $(r=0,17 ; r=0,21)$. Obecně jsou subškály přesnějšími prediktory specifického chování. Celkově hodnotíme kriteriální validitu jako uspokojivou. Z našeho shrnutí vyplývá, že je tato metoda schopna predikovat určité specifické projevy chování, které jsou pro obsah dané škály smysluplné (např. souvislost neuroticismu s tendencí odpouštět sám sobě). Metoda tedy pravděpodobně má určitou souvislost s konstrukty, které hodlá měřit.

Většina těchto údajů pochází ze zahraničních studií prováděných na NEO-PI-R. Jak píše Hřebíčková a Jelínek (2019) hlavním omezením české validizační studie je absence konvergentní a kriteriální validity. Nutná by byla administrace metod měřících obdobné teoretické konstrukty a predikce vymezených psychologických charakteristik či určitého chování, např. akademická úspěšnost, životní spokojenost.

\section{Faktorová struktura}

Pětifaktorová klasifikace osobnosti není přijímána bez výhrady. Např. Block (2010) se vymezuje a upozorňuje, že faktorovou analýzu nemůžeme ztotožňovat s realitou, poskytuje nám pouze různé variace možného výkladu reality.

Někteří autoři předpokládají hierarchickou strukturu faktorů. Např. Eysenck (1992) předkládá, že svědomitost a přívětivost jsou subfaktory psychoticismu, jiní autoři zase předpokládají, že faktory mají různou hierarchickou strukturu. Například DeYoung, Peterson a Higgins (cit. podle Bäckström, Björklund, \& Larsson, 2009) dokládají, že struktura loadingů může být vysvětlena existencí dvou faktorů vyššího řádu, které nazývají plasticita a stabilita. Další navrhovaný hierarchický model je komplexně strukturovaný tak, že na vrcholu struktury je jeden jediný faktor, který se manifestuje (realizuje) skrze dva faktory nižšího řádu do pěti, šesti, či možná sedmi výsledných faktor (Ashton, Lee, \& Golderg, 2004, cit. podle Bäckström, Björklund, \& Larsson, 2009).

V českém prostředí (konkrétně na české verzi NEO inventářů) byla zkoumána faktorová struktura pomocí explorační faktorové analýzy Hřebíčkovou a Urbánkem (2001, cit. podle Hřebíčková, Jelínek, 2019), a to s různými způsoby rotace, přičemž ve faktorové struktuře nebyl rozdíl (původní Goldbergova teorie postuluje, že faktory jsou navzájem ortogonální, jiní to ale vyvracejí a požadavek na nekorelovanost považují za nerealistickou podmínku (viz Block, 2010)). Dále bylo při ověřování faktorové struktury NEO-PI-3 Hřebíčkovou a Jelínkem (2019) extrahováno pět faktorů, přičemž všechny subškály dosahují alespoň faktorového náboje 0,40 a většího na předmětném faktoru. Pouze $v 5$ př́padech se objevily sekundární faktorové náboje na dalších subškálách. Costa a McCrae (cit. podle Hřebíčková a Jelínek, 2019) považují sekundární faktorové náboje za přiměřené tehdy, když se dají věcně interpretovat. Tak například subškála vřelost má sekundární faktorový náboj na přívětivosti $(0,46)$, tuhle 
subškálu však Goldberg (cit. podle Hřebíčková a Jelínek, 2019) zahrnul právě pod přívětivost. Tato faktorová struktura mj. dosahovala shody mezi metodami NEO-PI-3 a NEO-PI-R a taktéž mezi českou a americkou verzí NEO-PI-3.

Konfirmační faktorová analýza provedená na českém vzorku dosahovala poměrně slabé shody modelu $s$ daty, a to $\mathrm{v}$ prrípadě různě zvolených rotací $(\mathrm{CFI}=0,611 \mathrm{v}$ př́ípadě modelu $\mathrm{s}$ korelovanými faktory, $\mathrm{CFI}=0,560 \mathrm{v}$ případě modelu s nekorelovanými faktory). Hřebíčková a Jelínek (2019) k provedené analýze uvádějí, že zátěže jednotlivých subškál odpovídajících faktorů jsou na akceptovatelných úrovních.

Výsledky EFA naznačují, že je faktorová struktura metody na uspokojivé úrovni. Faktorové náboje jsou na příslušné škále vždy vyšší než 0,40 , sekundární faktorové náboje se objevily pouze v pěti případech. Výsledky CFA již tak uspokojivé výsledky nepřinesly. V tomto př́padě se projevuje problém ortogonality jednotlivých dimenzí osobnosti tak, jak je pětifaktorový model osobnosti postuluje. I přesto, že v konfirmační faktorové analýze byly faktory korelované, nedosahuje celkový model příliš dobré shody s daty (ač dosahuje lepší shody než ortogonální model) a nepřináší tak dobré důkazy o validitě.

\section{Reliabilita}

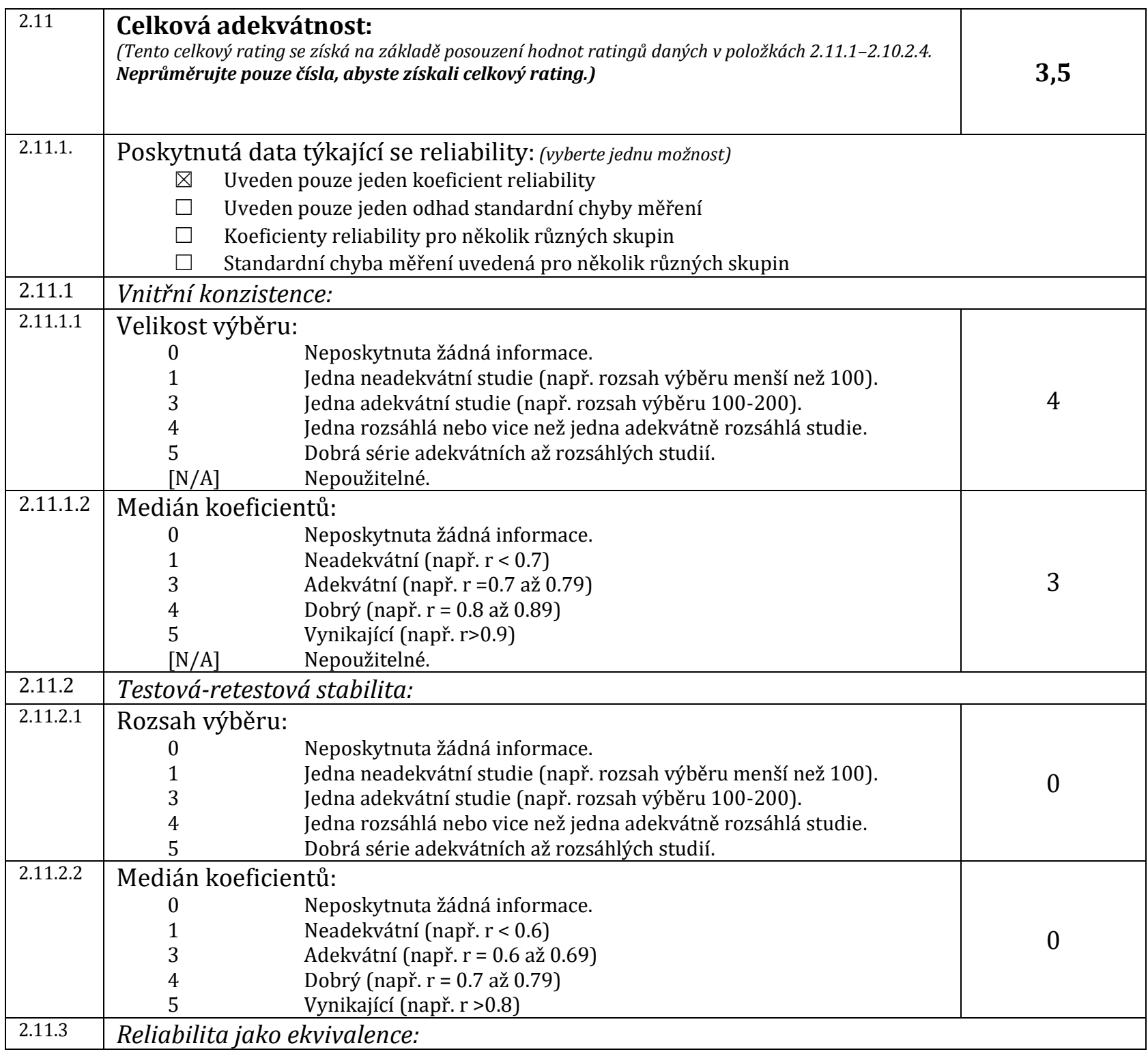




\begin{tabular}{|c|c|c|c|}
\hline 2.11 .3 .1 & $\begin{array}{l}\text { Rozsah výběru: } \\
\quad 0 \\
1 \\
3 \\
4 \\
5 \\
{[\mathrm{~N} / \mathrm{A}]}\end{array}$ & $\begin{array}{l}\text { Neposkytnuta žádná informace. } \\
\text { Jedna neadekvátní studie (např. rozsah výběru menš́i než 100). } \\
\text { Jedna adekvátní studie (např. rozsah výběru 100-200). } \\
\text { Jedna rozsáhlá nebo vice než jedna adekvátně rozsáhlá studie. } \\
\text { Dobrá série adekvátních až rozsáhlých studií. } \\
\text { Nepoužitelné. }\end{array}$ & 0 \\
\hline 2.11 .3 .2 & $\begin{array}{l}\text { Medián koeficie } \\
\quad 0 \\
1 \\
3 \\
4 \\
5 \\
{[\text { N/A ] }}\end{array}$ & $\begin{array}{l}\text { ntů: } \\
\text { Neposkytnuta žádná informace. } \\
\text { Neadekvátní (napřr. } r<0.6 \text { ) } \\
\text { Adekvátní (napřr. } r=0.6 \text { až } 0.69) \\
\text { Dobrý (napřr. } r=0.7 \text { až } 0.79) \\
\text { Vynikajíć́ (napřr. r }>0.8 \text { ) } \\
\text { Nepoužitelné }\end{array}$ & 0 \\
\hline \multicolumn{4}{|c|}{$\begin{array}{l}\text { 2.11.4 Komentáře recenzentů k reliabilitě: } \\
\text { - Komentujte intervaly spolehlivosti pro koeficienty reliability } \\
\text { - Uved'te Spearmanovy-Brownovy ekvivalenty }\end{array}$} \\
\hline \multicolumn{4}{|c|}{$\begin{array}{l}\text { Reliabilita české verze metody byla ověřována pouze na základě Cronbachova koeficientu } \\
\text { alfa měřící vnitřní konzistenci položek. Ta se pohybuje v rozmezí hodnot od } 0,9 \text { po } 0,94 \text { pro } \\
\text { hlavní škály. Vnitřní konzistence subškál se pohybuje od } 0,43 \text { pro subškálu } 06: \text { hodnoty po } \\
0,85 \text { pro subškálu N3: depresivnost. Většina subškál má uspokojivou reliabilitu (tj. nad } 0,70 \text { ), } \\
\text { problematické jsou } 4 \text { subškály mající reliabilitu pod } 0,69 \text {. Jedná se o subškály poddajnost, } \\
\text { hodnoty, aktivnost a impulzivnost. Všechny tyto subškály s výjimkou impulzivnosti jsou } \\
\text { problematické napříč různými národnostními verzemi. Costa a McCrae (cit. podle manuálu, } \\
\text { 2016) argumentují, že tyto škály vykazují retestovou stabilitu a mají vysokou korelaci s } \\
\text { kritériem. Zmiňují klasickou úvahu, že vysoká vnitřní konzistence mǔže souviset jen s } \\
\text { využitím obsahově shodných položek. Nízká vnitřní konzistence problematických subškál je } \\
\text { způsobena obsahově odlišnými položkami, které však podle autorů přesto měří stejný rys. } \\
\text { Medián Cronbachovy a je } 0,91 \text { pro hlavní škály a } 0,79 \text { pro subškály. Test-retest reliabilita } \\
\text { není pro českou verzi metody určena. Americká studie (Costa, Herbst, McCrae, \& Siegler, } \\
\text { 2000) poskytuje poměrně vysokou test-retest reliabilitu na vzorku } 2274 \text { participantů } \\
\text { měřenou pomocí Pearsonovy korelace po } 9 \text { letech. Korelace se pohybuje v rozmezí od } 0,76 \\
\text { do 0,84 pro hlavní škály a od } 0,64 \text { do } 0,80 \text { pro subškály. Medián těchto hodnot je } 0,72 \text {. Jelikož } \\
\text { i jiné zahraniční studie poskytují obdobné hodnoty (McCrae, Yik, Trapnell, Bond, \& Paulhus, } \\
\text { 1998; Rantanen, Metsäpelto, Feldt, Pulkkinen, \& Kokko, 2007), můžeme předpokládat, že se } \\
\text { dají výsledky do jisté míry generalizovat i na české prostředí. Validizační studie, která by } \\
\text { určila test-retest reliabilitu pro českou verzi, by nicméně nepochybně byla užitečná. }\end{array}$} \\
\hline \multicolumn{4}{|c|}{$\begin{array}{l}\text { Ve shrnutí můžeme říci, že vnitřní konzistence jednotlivých škál je na adekvátní, až dobré } \\
\text { úrovni. Pokud bychom vzali do úvahy také zahraniční studie, test-retest variabilita je např́č } \\
\text { škálami dobrá až vynikající. Z toho vyplývá, že metoda je poměrně spolehlivá a napříč } \\
\text { opakovanými měřeními dosáhneme obdobných výsledků. }\end{array}$} \\
\hline \multicolumn{4}{|c|}{$\begin{array}{l}\text { Pro detailnější popis poskytujeme následující přehled uvádějící reliabilitu pro jednotlivé } \\
\text { subškály: }\end{array}$} \\
\hline \multicolumn{4}{|c|}{ [] Žádné informace neposkytnuty } \\
\hline \multicolumn{4}{|c|}{ [4] Neadekvátní } \\
\hline \multicolumn{4}{|c|}{ [14] Adekvátní } \\
\hline & & & \\
\hline
\end{tabular}


Část 8:

Kvalita počítačově generovaných zpráv:

Položky mají být posuzovány n/a nebo 0 až 5 (poloviční rating je přijatelný)

Rating

\begin{tabular}{|c|c|c|}
\hline 2.12 & $\begin{array}{l}\text { Celková adekvátnost počítačově generovaných zpráv: } \\
\text { (Tento celkový rating se získá na základě posouzení hodnot ratingů daných pro položky 2.12.1-2.12.7. } \\
\text { Neprůměrujte pouze hodnoty, abyste získali celkový rating.) }\end{array}$ & 4 \\
\hline 2.12 .1 & 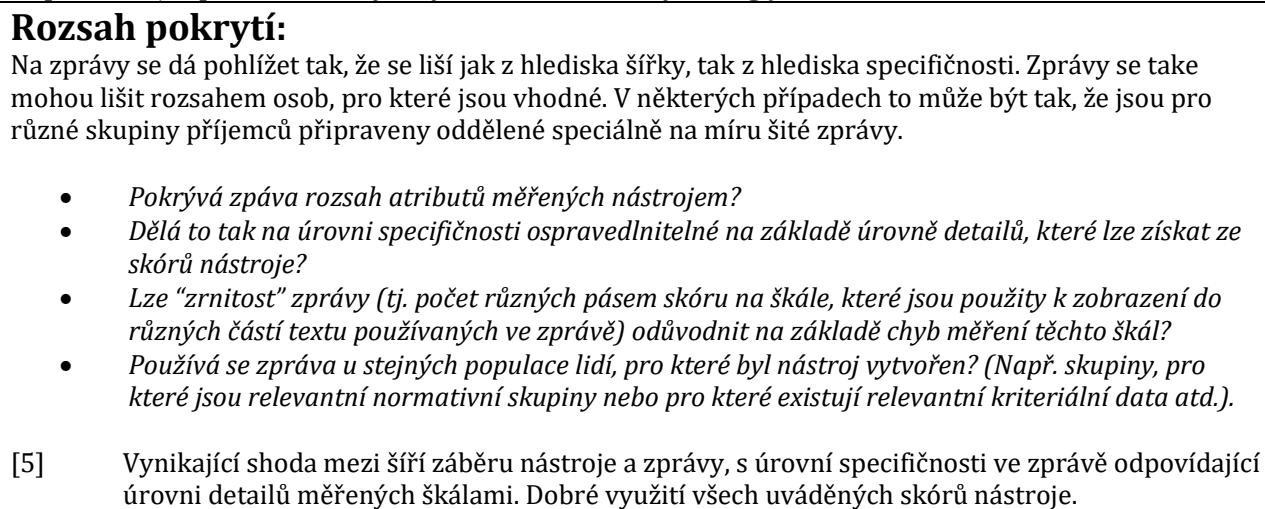 & 4,5 \\
\hline 2.12 .2 & $\begin{array}{l}\text { Reliabilita } \\
\text { • Jak konsistentní jsou zprávy ve své interpretaci podobných sad skórů? } \\
\text { - } \quad \begin{array}{l}\text { Pokud je obsah zprávy variabilní (např. náhodným výběrem z ekvivalentních částí textu), je to } \\
\text { prováděno uspokojivě? }\end{array} \\
\text { - Je interpretace skórú a rozdílů mezi skóry ospravedlnitelná z hlediska chyb měření škál? } \\
\text { [5] } \quad \begin{array}{l}\text { Vynikající konsistence při interpretaci a přiměřená varování poskytnutá u tvrzení, interpretací } \\
\text { a doporučení týkajících se souvisejících chyb měření. }\end{array} \\
\end{array}$ & 3 \\
\hline 2.12 .3 & $\begin{array}{l}\text { Relevance neboli validita } \\
\text { Spojení mezi nástrojem a obsahem zprávy může být bud' vysvětlena v rámci zprávy nebo dokumentováno } \\
\text { odděleně. Kde jsou zprávy založené na klinickém úsudku, by měl být dokumentován process, kterým } \\
\text { expert(i) vytvářel(i) obsah a pravidla dávající do vztahu skóry a obsah. } \\
\text { - Jak silný je vztah mezi obsahem zprávy a skóry nástroje? Do jaké míry jde zpráva za nebo se } \\
\text { rozchází s informacemi poskytovanými skóry nástroje? } \\
\text { - Je obsah zprávy v jasném vztahu k charakteristikám měřeným nástrojem? } \\
\text { Poskytuje rozumné závěry o kritériích, ke kterým mǔžeme očekávat, že budou takové } \\
\text { charakteristiky ve vztahu? } \\
\quad \text { Jaké empirické důkazy jsou poskytnuty, které ukazují, že tyto vztahy skutečně existují? } \\
\text { Je relevantní uvažovat jak o konstruktové validitě zprávy (tj. míře, do jaké poskytuje interpretaci, která je } \\
\text { ve shodě s příslušnými konstrukty) a kriteriální validitě (t). kde jsou formulovány výroky, které lze davit } \\
\text { zpětně do vztahu s empirickými daty). } \\
\text { [5] }\end{array}$ & 3 \\
\hline 2.12 .4 & 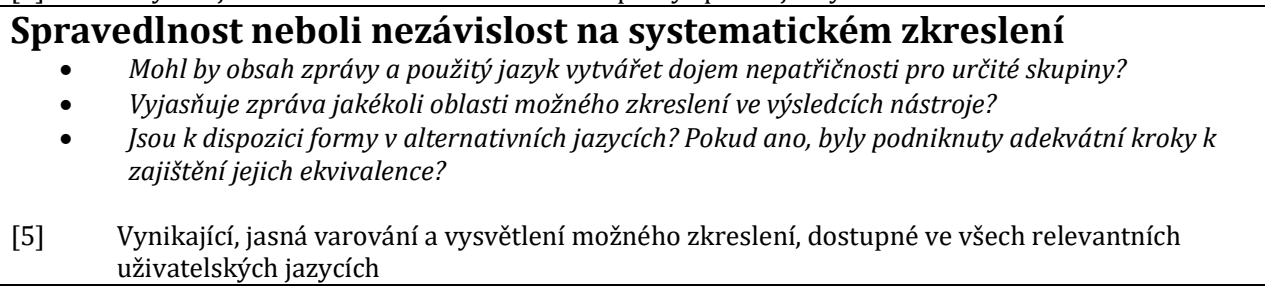 & 4 \\
\hline
\end{tabular}




\begin{tabular}{|c|c|c|}
\hline 2.12 .5 & $\begin{array}{l}\text { Přijatelnost } \\
\text { Ta bude velmi záviset na komplexnosti jazyka použitého ve zprávě, složitosti popisovaných konstruktů a } \\
\text { účelu, pro jaký je určena. } \\
\text { • Dá se očekávat, že forma a obsah zprávy budou přijatelné zamýšleným př́ijemcưm? } \\
\text { - Je zpráva napsána jazykem, který je přiměřený pravděpodobným úrovním počtárské zběhlosti a } \\
\text { gramotnosti predpokládaného čtenáre? } \\
\text { [5] Velmi vysoká přijatelnost, dobře navržená a dobře se hodící předpokládaným příjemcům }\end{array}$ & 4 \\
\hline 2.12 .6 & $\begin{array}{l}\text { Praktičnost } \\
\text { Otázky praktičnosti take ovlivňují přijatelnost. Hlavní praktická výhoda počítačově generovaných zpráv je } \\
\text { ta, že šetří čas osoby, která by jinak musela zprávu vytvořit. Když tato osoba není koncový uživatel, } \\
\text { argumenty týkající se praktičnosti mohou být obtí̌něji formulovatelné. } \\
\text { • Kolik času šetř́ každá zpráva uživateli? } \\
\quad \text { Kolik času zabere čtení a používání každé zprávy? } \\
\text { [5] Vynikající z hlediska efektivity a hodnoty. }\end{array}$ & \\
\hline 2.12 .7 & $\begin{array}{l}\text { Délka } \\
\text { Toto je aspekt praktičnosti a měl by se projevit v tomto ratingu. Konkrétněji poskytuje index } \\
\text { poměru kvantity výstupu ku vstupu. Počet škál, na kterých je založen obsah zprávy, je } \\
\text { považován za vstup, a počet stránek zprávy (mimo titulních stránek, poznámek týkajících se } \\
\text { copyrightu atd.) jsou považovány za výstup. } \\
\text { Pro výpočet tohoto indexu sečtěte počet škál včetně odvozených a kompozitních škál (např. pro } \\
\text { osobnostní míry, faktorové škály vyššího řádu, škály pro typy týmŭ, styly vedení atd. Mohou } \\
\text { být odvozeny ze základních škál). } \\
\qquad \begin{array}{l}1 . \quad \text { Vydělte celkový počet stránek počtem škál. } \\
2 \text {. Vynásobte tento zlomek } 10 \text { a zaokrouhlete výsledek na nejbližší celé číslo. }\end{array} \\
\text { Hodnoty vyšší než } 10 \text { obecně pravděpodobně indikují zprávy, které jsou nadměrně dlouhé a } \\
\text { přehnaně interpretující } \\
\text { Např.: Vývojová zpráva - } 8 / 7 \text { x } 10=11.42 \text {. }\end{array}$ & 11 \\
\hline
\end{tabular}

\section{Č́st 9:}

\section{Závěrečné hodnocení:}

\subsection{Hodnotící zpráva testu:}

Tato část by měla obsahovat stručné, jasně obhájené posouzení nástroje/produktu. Mělo by popisovat jeho pro a proti a poskytnout určitá obecná doporučení týkající se toho, jak a kdy by se měl používat - spolu s varováními (kde jsou potřebná) týkajícími se případů, kde by se používat neměl.

Co se spolehlivosti metody týče, jednotlivé škály poskytují uspokojivou vnitřní konzistenci, která je pro zamýšlené účely metody použitelná. Výsledky jsou stabilní jak po jednom týdnu, tak i dvou či devíti letech od posledního měření. Můžeme tedy předpokládat, že se při opakovaném měření dostaví obdobné výsledky. Co se týče validity metody, výsledky explorační faktorové analýzy jsou uspokojivé, zamýšlenou faktorovou strukturu lze nalézt napříč kulturními kontexty. Konfirmační faktorová analýza v českém prostředí nepřinesla př́liš dobrou shodu modelu s daty. Jednotlivé škály korelují uspokojivě se sebeposouzením podle adjektiv s výjimkou v případě Otevřenosti vưči zkušenostem. Tato škála se ukazuje jako problematická, s adjektivy totiž př́liš nekoreluje, což může být způsobeno odlišným obsahem tohoto faktoru ve srovnání s NEO inventáři. Metoda dále dosahuje adekvátních korelací s obdobnými konstrukty (viz Eysenckova škála) a ze zahraničních studií vyplývá, že škály predikují různá kritéria poměrně obstojně. Zda metoda opravdu zachycuje inherentní rysy osobnosti mající neurobiologické základy, je diskutabilní (Block, 2010). 


\subsection{Závěry:}

Ve shrnutí můžeme říct, že je reliabilita a validita metody obstojná. Závěrem tedy považujeme metodu NEO-PI-3 za užitečný nástroj, který nabízí jistý rámec pro porozumění osobnosti a vymezených 5 faktorů za jeden z možných způsobů, jak klasifikovat osobnostní strukturu. Zásadní je však kontext použití, detailní znalost jednotlivých subškál a realistický přístup k využití metody. Navíc formulace některých položek se zdá vybízet k sociální žádoucnosti (např. považuji se za dobročinného člověka) či mohou být obtížné na osobní posouzení (např. nevytahuji se).

Z těchto informací bychom rádi na závěr formulovali několik doporučení: Zaprvé, při poradenství či v rámci terapie doporučujeme využívat tuto metodu za vyjasněným účelem, tj. ne apriori pro porozumění člověku, ale v rámci sledování určité zakázky. Zadruhé, metoda by měla být využita pouze $\mathrm{v}$ kontextu, který předpokládá motivaci klienta $\mathrm{k}$ dobrání se co nejpřesnějších výsledků. Nevhodné je tedy využití v rámci pracovního pohovoru či testování zaměstnanců. Zatřetí, metoda by měla být využívána spíše jako doplněk k porozumění osobnosti. Předpřipravený teoretický pohled vede $\mathrm{k}$ jisté redukci osobnosti jedince a výslednou interpretaci je zásadní chápat v poznání idiografického kontextu dané osoby, které předchází samotnému testování. Úskalí totiž spočívá v chápání lidské osobnosti apriori na základě vymezených dimenzí.

Vhodné využití vidíme např. v psychodiagnostické činnosti (testování za účelem identifikace silných stránek osobnosti), ve školní psychologii (identifikace problematických stránek souvisejících s obtížemi v kolektivu), v poradenské oblasti (určení interpersonálního stylu za účelem pomoci při výběru budoucího povolání) a ve výzkumné činnosti.

\subsection{Doporučení (vyberte jedno) \\ Všechny následující charakteristiky uvedené níže by měly mít ratingy [n/a], [2], [4], [5], pokud by měl být nástroj „doporučen“ pro obecné použití (hodnocení 5 nebo 6): \\ [2.9] Normy a referenční skupiny [2.10.1] Konstruktová validita \\ [2.10.2] Kriteriální validita \\ [2.11] Reliabilita - celková \\ [2.12] Počítačově generované \\ zprávy \\ Pokud má kterýkoli z výše uvedených ratingů hodnotu [] nebo [1], nástroj by měl být klasifikován pod doporučením 1, 2, 3 nebo 4, nebo klasifikován pod doporučením 7 "jiné” s adekvátním vysvětlením.}

1 Pouze výzkumný nástroj. Ne pro užití v praxi.

2 Vhodný pouze pro užití expertním uživatelem za pečlivě kontrolovaných podmínek nebo ve velmi omezených aplikačních oblastech

3 Vhodný pro použití pod supervizí $\mathrm{v}$ aplikační(ch) oblasti(ech) definovaných distributorem, libovolnými uživateli s obecnými kompetencemi pro používání a administraci testů

4 Vyžaduje další vývoj. Vhodný pouze pro použití ve výzkumu.

凶 5 Vhodný pro používání v aplikační(ch) oblasti(ech) definovaných distributorem, uživateli testů, kteří splňují speciální kvalifikační požadavky distributora

6 Vhodný pro sebevyšetření bez supervise $\mathrm{v}$ aplikační(ch) oblasti(ech) definovaných distributorem

7 Jiné: Klikněte sem a zadejte text.

\section{Odkazy k poznámkám a bibliografie}

Ashton, M. C., \& Lee, K. (2007). Empirical, theoretical, and practical advantages of the HEXACO model of personality structure. Personality and social psychology review, 11(2), 150-166. 
Bäckström, M. (2007). Higher-order factors in a five-factor personality inventory and its relation to social desirability. European Journal of Psychological Assessment, 23(2), 63-70.

Bäckström, M., Björklund, F., \& Larsson, M. R. (2009). Five-factor inventories have a major general factor related to social desirability which can be reduced by framing items neutrally. Journal of Research in Personality, 43(3), 335-344.

Block, J. (2010). The five-factor framing of personality and beyond: Some ruminations. Psychological Inquiry, 21(1), 2-25.

Conard, M. A. (2006). Aptitude is not enough: How personality and behaviour predict academic performance. Journal of Research in Personality, 40(3), 339-346.

Costa Jr, P. T., Herbst, J. H., McCrae, R. R., \& Siegler, I. C. (2000). Personality at midlife: Stability, intrinsic maturation, and response to life events. Assessment, 7(4), 365-378.

Ekehammar, B., \& Akrami, N. (2007). Personality and prejudice: From Big Five personality factors to facets. Journal of personality, 75(5), 899-926.

Farsides, T., \& WoodWeld, R. (2003). Individual differences and undergraduate academic success: the roles of personality, intelligence, and application. Personality and Individual Differences, 34, 1225-1243.

Hřebíčková, M., \& Jelínek, M. (2019). NEO osobnostní inventář 3: Základní psychometrické charakteristiky české verze NEO-PI-3. Československá Psychologie, 63(2), 160-176.

McCrae, R. R., Costa, P. T., Martin, T. A., Oryol, V. E., Rukavishnikov, A. A., Senin, I. G., Hřebíčková, M. \& Urbánek, T. (2004). Consensual validation of personality traits across cultures. Journal of Research in Personality, 38, 179-201.

McCrae, R. R., \& Costa Jr, P. T. (2008). The five-factor theory of personality.

McCrae, R. R., Yik, M. S., Trapnell, P. D., Bond, M. H., \& Paulhus, D. L. (1998). Interpreting personality profiles across cultures: Bilingual, acculturation, and peer rating studies of Chinese undergraduates. Journal of Personality and Social Psychology, 74(4), 1041.

Musek, J. (2007). A general factor of personality: Evidence for the big one in the five factor model. Journal of Research in Personality, 41, 1213-1233.

Paulhus, D. L., Bruce, M. N., \& Trapnell, P. D. (1995). Effects of self-presentation strategies on personality profiles and their structure. Personality and Social Psychology Bulletin, 21(2), 100108.

Paunonen, S. V., \& Ashton, M. C. (2001). Big five factors and facets and the prediction of behavior. Journal of personality and social psychology, 81(3), 524.

Ross, S. R., Kendall, A. C., Matters, K. G., Mark S. Rye, M. S. R., \& Wrobel, T. A. (2004). A personological examination of self-and other-forgiveness in the five factor model. Journal of Personality Assessment, 82(2), 207-214. 
Rantanen, J., Metsäpelto, R. L., Feldt, T., Pulkkinen, L. E. A., \& Kokko, K. (2007). Long-term stability in the Big Five personality traits in adulthood. Scandinavian Journal of Psychology, $48(6), 511-518$.

Szarota, P., Zawadzki, B., \& Strelau, J. (2002). Big five domain and gender as determinants of rater agreement: a comparison based on self-and peer-rating on the Polish Adjective List. Personality and Individual Differences, 33(8), 1265-1277.

\section{Měřené konstrukty:}

Metoda NEO-PI-3 obsahuje celkově 5 hlavních škál. Každá škála je dále členěna na 6 subškál, celkově tedy metoda čítá 5 škál a 30 subškál.

Neuroticismus - úzkostnost, hněvivost, depresivnost, rozpačitost, impulzivita, zranitelnost

Extraverze - vřelost, družnost, asertivita, aktivnost, vyhledávání vzrušení, pozitivní emoce

Otevřenost ke zkušenostem - fantazie, estetické prožívání, prožívání, novátorské činnosti, ideje, hodnoty

Přívětivost - důvěra, upř́mnost, altruismus, poddajnost, skromnost, jemnocit

Svědomitost - způsobilost, pořádkumilnost, zodpovědnost, cílevědomost, disciplinovanost, rozvážnost 


\section{Prostor pro další poznámky pro redakci Testfóra}

Na této a následujících stranách můžete vložit text a jiný obsah, který výše uvedený formulář neumožňuje, případně můžete vložit poznámky pro editory Testfóra. 